\title{
Climate change impacts and adaptation in forest management: a review
}

\author{
Rodney J. Keenan
}

Received: 1 September 2014 / Accepted: 10 December 2014 /Published online: 14 January 2015

(C) INRA and Springer-Verlag France 2015. This article is published with open access at Springerlink.com

\begin{abstract}
- Key message Adaptation of forest management to climate change requires an understanding of the effects of climate on forests, industries and communities; prediction of how these effects might change over time; and incorporation of this knowledge into management decisions. This requires multiple forms of knowledge and new approaches to forest management decisions. Partnerships that integrate researchers from multiple disciplines with forest managers and local actors can build a shared understanding of future challenges and facilitate improved decision making in the face of climate change.

- Context Climate change presents significant potential risks to forests and challenges for forest managers. Adaptation to climate change involves monitoring and anticipating change and undertaking actions to avoid the negative consequences and to take advantage of potential benefits of those changes.

- Aims This paper aimed to review recent research on climate change impacts and management options for adaptation to climate change and to identify key themes for researchers and for forest managers.

- Methods The study is based on a review of literature on climate change impacts on forests and adaptation options for forest management identified in the Web of Science database, focusing on papers and reports published between 1945 and 2013.
\end{abstract}

Handling Editor: Erwin Dreyer

This research was partly undertaken during the period the author was Director of the Victorian Centre for Climate Change Adaptation Research and part-funded by the Victorian Government. It was completed with support from the University of Melbourne under a Special Studies Program grant.

\section{R. J. Keenan $(\bowtie)$}

Department of Forest and Ecosystem Science, The University of Melbourne, 221 Bouverie St., Carlton, VIC 3010, Australia

e-mail: rkeenan@unimelb.edu.au
- Results One thousand one hundred seventy-two papers were identified in the search, with the vast majority of papers published from 1986 to 2013. Seventy-six percent of papers involved assessment of climate change impacts or the sensitivity or vulnerability of forests to climate change and $11 \%$ (130) considered adaptation. Important themes from the analysis included (i) predicting species and ecosystem responses to future climate, (ii) adaptation actions in forest management, (iii) new approaches and tools for decision making under uncertainty and stronger partnerships between researchers and practitioners and (iv) policy arrangements for adaptation in forest management.

- Conclusions Research to support adaptation to climate change is still heavily focused on assessing impacts and vulnerability. However, more refined impact assessments are not necessarily leading to better management decisions. Multi-disciplinary research approaches are emerging that integrate traditional forest ecosystem sciences with social, economic and behavioural sciences to improve decision making. Implementing adaptation options is best achieved by building a shared understanding of future challenges among different institutions, agencies, forest owners and stakeholders. Research-policy-practice partnerships that recognise local management needs and indigenous knowledge and integrate these with climate and ecosystem science can facilitate improved decision making.

Keywords Climate change - Adaptation - Vulnerability · Policy $\cdot$ Forest management $\cdot$ Impacts $\cdot$ Effects $\cdot$ Responses

\section{Introduction}

Anthropogenic climate change presents potential risks to forests and future challenges for forest managers. Responding to 
climate change, through both mitigation and adaptation, may represent a paradigm shift for forest managers and researchers (Schoene and Bernier 2012). Climate change is resulting in increasing air temperature and changing precipitation regimes, including changes to snowfall and to the timing, amount and inter-annual variability of rainfall (IPCC 2013). Forests are widespread, long-lived ecosystems that are both intensively and extensively managed. They are potentially sensitive to these longer term climatic changes, as are the societies and economies that depend on them (Bernier and Schöne 2009). Climate change increases the potential consequences of many existing challenges associated with environmental, social or economic change.

Whilst forest ecosystems are resilient and many species and ecosystems have adapted historically to changing conditions, future changes are potentially of such magnitudes or will occur at rates that are beyond the natural adaptive capacity of forest species or ecosystems, leading to local extinctions and the loss of important functions and services, including reduced forest carbon stocks and sequestration capacity (Seppälä et al. 2009).

Recent global warming has already caused many changes in forests (Lucier et al. 2009). Aspects of climate change may be positive for some tree species in some locations. Tree growth is observed to be increasing in some locations under longer growing seasons, warmer temperatures and increased levels of $\mathrm{CO}_{2}$. However, many projected future changes in climate and their indirect effects are likely to have negative consequences for forests. Observed shifts in vegetation distribution (Kelly and Goulden 2008; Lenoir et al. 2010) or increased tree mortality due to drought and heat in forests worldwide (Allen et al. 2010) may not be due to humaninduced climate change but demonstrate the potential impacts of rapid climate change. These impacts may be aggravated by other human-induced environmental changes such as increases in low elevation ozone concentrations, nitrogenous pollutant deposition, the introduction of exotic insect pests and pathogens, habitat fragmentation and increased disturbances such as fire (Bernier and Schöne 2009). Other effects of climate change may also be important for forests. Sea level rise is already impacting on tidal freshwater forests (Doyle et al. 2010) and tidal saltwater forests (mangroves) are expanding landward in sub-tropical coastal reaches taking over freshwater marsh and forest zones (Di Nitto et al. 2014).

With projected future change, species ranges will expand or contract, the geographic location of ecological zones will shift, forest ecosystem productivity will change and ecosystems could reorganise following disturbances into ecological systems with no current analogue (Campbell et al. 2009; Fischlin et al. 2009). Forests types differ in their sensitivity to climatic change. Bernier and Schöne (2009) considered boreal, mountain, Mediterranean, mangrove and tropical moist forests most vulnerable to climate change. However, there has been recent debate about the vulnerability of tropical moist forests (Corlett 2011; Huntingford et al. 2013; Feeley et al. 2012), and temperate forests in areas subject to drier climates may be more at risk (Choat et al. 2012).

Adapting to these changing and uncertain future conditions can be considered from a number of perspectives (McEvoy et al. 2013). Policy and management might be directed at avoiding or reducing the impact of climate-related events, reducing vulnerability to future climatic conditions, managing a broader suite of climate 'risks' or increasing resilience and capacity in forest ecological and production systems to recover from climate 'shocks'.

Adapting forest management to climate change involves monitoring and anticipating change and undertaking actions to avoid the negative consequences or take advantage of potential benefits of those changes (Levina and Tirpak 2006). Adopting the principles and practices of sustainable forest management (SFM) can provide a sound basis for addressing the challenges of climate change. However, Innes et al. (2009) pointed out that our failure to implement the multi-faceted components of sustainable forest management in many forests around the world is likely to limit capacity to adapt to climate change. Forest managers will need to plan at multiple spatial and temporal scales and adopt more adaptive and collaborative management approaches to meet future challenges.

Whilst forest managers are accustomed to thinking in long time scales - considering the long-term implications of their decisions and factoring in uncertainty and unknowns into management-many are now responding to much shorter term social or economic imperatives. Local forestry practices are often based on an implicit assumption that local climate conditions will remain constant (Guariguata et al. 2008). Other social and economic changes will also continue to drive changes in forest management (Ince et al. 2011). For example, a growing global population, rapid economic development and increased wealth are driving demand for food and fibre crops and forest conversion to agriculture in many developing countries (Gibbs et al. 2010). Climate change mitigation objectives are increasing demands for wood-based bioenergy and the use of wood in construction and industrial systems. Increasing urbanisation is changing the nature of social demands on forests, and decreasing rural populations is limiting the availability of labour and capacity for intensive forest management interventions.

Ecosystem-based adaptation is being promoted as having the potential to incorporate sustainable management, conservation and restoration of ecosystems into adaptation to climate change (IUCN 2008). This can be achieved more effectively by integrating ecosystem management and adaptation into national development policies through education and outreach to raise societal awareness about the value of ecosystem services (Vignola et al. 2009).

Kimmins (2002) invoked the term 'future shock', first coined by Toffler (1970) to describe the situation where 
societal expectations from forests were changing faster than the institutional capacity for change in forest management organisations. The pace of climate change is likely to intensify this phenomenon. Empirically based management based on traditional 'evidence-based' approaches therefore will potentially not develop quickly enough for development of effective future management options. How can managers consider rapid change and incorporate the prospect of very different, but uncertain, future climatic conditions into their management decisions? What types of tools are needed to improve decision making capacity?

This study aimed to review the literature on studies to support forest management in a changing climate. It builds on the major review of Seppala (2009), in particular Chapter 6 of that report by Innes et al. (2009).

\section{Methods}

The study involved a systematic assessment of the literature based on the database Web of Science (Thomson-Reuters 2014), an online scientific citation indexing service that provides the capacity to search multiple databases, allowing indepth exploration of the literature within an academic or scientific discipline.

The following search terms were used in the titles of publications:

(forest ${ }^{*}$ or tree* or (terrestrial and ecosystem)) and climat* and (adapt* or impact* or effect* or respons*) and

(forest* or tree*) and climat* and vulnerabilit* or sensitivit $\left.{ }^{*}\right)$

The search was restricted to publications between 1945 and 2013. References related solely to climate change mitigation were excluded, as were references where the word 'climate' simply referred to a study in a particular climatic zone. This left a database of 1172 publications for analyses (a spreadsheet of the papers revealed in the search can be obtained from the author). References were classified into various types of studies and different regions, again based on the titles. Not all papers identified in the search are referenced. The selection of themes for discussion and papers for citation was a subjective one, based on scanning abstracts and results from relevant individual papers. The focus was important themes from key papers and literature from the last 5 years. The review includes additional papers not revealed in the search relating to these themes including selected papers from the literature in the year 2014.

\section{Results}

Of the published papers relating to climate impacts or adaptation selected for analysis, the vast majority of papers were published from 1986 onwards. The earliest paper dated from
1949 (Gentilli 1949) analysing the effects of trees on climate, water and soil. Most studies prior to 1986 (and even some published later) focused on the effects of trees on local or wider regional climate (Lal and Cummings 1979; Otterman et al. 1984; Bonan et al. 1992), the implications of climate variability (Hansenbristow et al. 1988; Ettl and Peterson 1995; Chen et al. 1999), studies of tree and forest responses across climatic gradients (Grubb and Whitmore 1966; Bongers et al. 1999; Davidar et al. 2007) or responses to historical climate (Macdonald et al. 1993; Huntley 1990; Graumlich 1993).

One thousand twenty-six papers specifically addressed future climate change (rather than historical climate or gradient analysis). Of these, $88 \%$ studied impacts, effects, vulnerability or responses to climate change in tree species, forests, forest ecosystems or the forest sector (Fig. 1). The first study analysing the potential impacts of future climate change on terrestrial ecosystems was published in 1985 (Emanuel et al. 1985 ) with other highly cited papers soon after (Pastor and Post 1988; Cannell et al. 1989).

Twelve percent of papers (129) considered adaptation options, including 10 papers on adaptation in the forest sector. The first papers to focus on adaptation in the context of climate change were in 1996 with a number of papers published in that year (Kienast et al. 1996; Kobak et al. 1996; Dixon et al. 1996). Publications were then relatively few each year until the late 2000s with numbers increasing to 11 in 2009, 22 in 2010 and 27 in 2011. Publications on adaptation dropped to 14 papers in 2013. The ratio of adaptation-related papers has increased more recently, with $19 \%$ of total publications on adaptation in the last 5 years. Most papers considering adaptation since the early 2000s have related to the integration of adaptation and forest management (e.g. Lindner 2000; Spittlehouse 2005; Kellomaki et al. 2008; Guariguata 2009; Bolte et al. 2009; Keskitalo 2011; Keenan 2012; Temperli et al. 2012).

Analyses of the implications of climate change for the forest sector have focused heavily on North America: Canada (Ohlson et al. 2005; Van Damme 2008; Rayner et al. 2013; Johnston et al. 2012) and the USA (Joyce et al. 1995; Blate et al. 2009; Kerhoulas et al. 2013); and Europe (Karjalainen et al. 2003; von Detten and Faber 2013). There has been a stronger consideration in recent years of social, institutional and policy issues (Ogden and Innes 2007b; Kalame et al. 2011; Nkem et al. 2010; Spies et al. 2010; Somorin et al. 2012) and the assessment of adaptive capacity in forest management organisations and in society more generally (Keskitalo 2008; Lindner et al. 2010; Bele et al. 2013a).

Regionally, there have been relatively few published journal articles on impacts or adaptation in forests in the Southern Hemisphere (Hughes et al. 1996; Williams 2000; Pinkard et al. 2010; Gonzalez et al. 2011; Mok et al. 2012; Breed et al. 2013), although there have been more studies in the grey literature for Australian forests (Battaglia et al. 2009; Cockfield et al. 2011; Medlyn et al. 2011; Stephens et al.

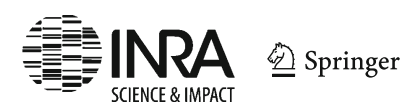


Fig. 1 Publication numbers by publication year for publications relating to climate change and forests from a search of the Web of Science database to the end of 2013 (1025 in total, 896 publications studied climate change impacts, responses or vulnerability, 129 studied adaptation)

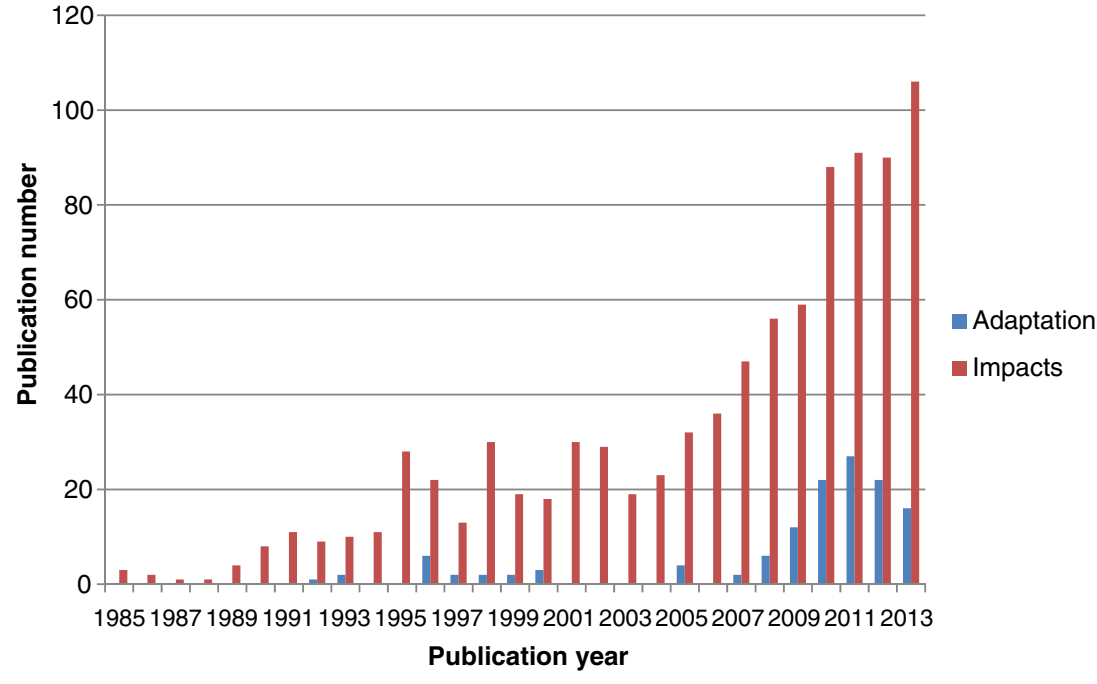

2012). There have been some valuable analyses for the tropics (Guariguata et al. 2008, 2012; Somorin et al. 2012; Feeley et al. 2012).

Analysis of the publications identified the following key themes: (i) predicting species and ecosystem responses to future climate, (ii) adaptation actions in forest management, (iii) new approaches and tools for decision making under uncertainty and stronger partnerships between researchers and practitioners and (iv) policy arrangements for adaptation in forest management. These are discussed in more detail below.

\subsection{Predicting species and ecosystem responses to future climate}

Forest managers have long used climatic information in a range of ways in planning and decision making. Climate information has been used extensively to define and map vegetation types and ecological zones and for modelling habitat distributions of vertebrates and invertebrates (Daubenmire 1978; Pojar et al. 1987; Thackway and Cresswell 1992), for species and provenance selection (Booth et al. 1988; Booth 1990) and seed zone identification (Johnson et al. 2004), for forest fire weather risk assessment and fire behaviour modelling (Carvalho et al. 2008), for modelling forest productivity (Battaglia et al. 2004) and analysing the dynamics of a range of ecological processes (Anderson 1991; Breymeyer and Melillo 1991). Predicting species responses to future climate change presents a different set of challenges, involving consideration of predictions of future climate that are often outside the historical range of variability of many species. These challenges are discussed in the next section.

\subsubsection{Species responses to climate}

Aitken et al. (2008) argued that there were three possible fates for forest tree populations in rapidly changing climatic conditions: persistence through spatial migration to track their ecological niches, persistence through adaptation to new conditions in current locations or the extirpation of the species. Predicting the potential fate of populations in these conditions requires the integration of knowledge across biological scales from individual genes to ecosystems, across spatial scales (for example, seed and pollen dispersal distances or breadth of species ranges) and across temporal scales from the phenology of annual developmental cycle traits to glacial and interglacial cycles.

Whilst there has been widespread use of climatic information to predict future distributions in species distribution models (SDMs, Pearson and Dawson 2003; Attorre et al. 2008; Wang et al. 2012; Ruiz-Labourdette et al. 2013), understanding of the range of climatic and non-climatic factors that will determine the future range of a particular species remains limited. Many now feel that SDMs are of limited value in adaptation decision making or species conservation strategies. Some of these limitations are summarised in Table 1.

For example, models indicate significant shifts in patterns of tree species distribution over the next century but usually without any intrinsic consideration of the biological capacity of populations to move, internal population dynamics, the extent and role of local adaptation or the effects of climate and land use (Aitken et al. 2008; Thuiller et al. 2008). In a recent study, Dobrowski et al. (2013) found that the predicted speed of movement of species to match the predicted rate of climate change appears to be well beyond the historical rates of migration. Whilst modelled outputs suggest that migration rates of $1000 \mathrm{~m}$ per year or higher will be necessary to track changing habitat conditions (Malcolm et al. 2002), actual migration rates in response to past change are generally considered to have been less than $100 \mathrm{~m}$ per year. This was reinforced by model predictions that incorporate species dispersal characteristics for five tree species in the eastern USA indicated very low probabilities of dispersal beyond 10-20 km from current species boundaries by 2100 (Iverson et al. 2004). 
Table 1 Limitations to species distribution models (SDMs) for predicting the impacts of climate change on forest tree species

\begin{tabular}{|c|c|c|}
\hline Challenge & Examples & References \\
\hline $\begin{array}{l}\text { Predicting capacity of species } \\
\text { to move }\end{array}$ & $\begin{array}{l}\text { Species have historically moved much more slowly than } \\
\text { future climate is projected to change. Humans may } \\
\text { have a role in shifting species distributions. Fragmentation } \\
\text { or lack of suitable habitat can limit movement }\end{array}$ & $\begin{array}{l}\text { Iverson et al. (2004), Dobrowski } \\
\text { et al. (2013), Clark (2007), } \\
\text { Corlett and Westcott (2013) }\end{array}$ \\
\hline Local adaptation & $\begin{array}{l}\text { Many species have the capacity to adapt to changes in } \\
\text { local conditions through refugia }\end{array}$ & Aitken et al. (2008) \\
\hline $\begin{array}{l}\text { Uncertainty in predicting future } \\
\text { climate, particularly } \\
\text { precipitation or aridity }\end{array}$ & $\begin{array}{l}\text { Water balance and aridity can be major factor in determining } \\
\text { future tree growth }\end{array}$ & $\begin{array}{l}\text { Dobrowski et al. (2013), } \\
\text { Wang et al. (2012) }\end{array}$ \\
\hline $\begin{array}{l}\text { Predicting and incorporating effects } \\
\text { of extreme events on tree species } \\
\text { populations }\end{array}$ & $\begin{array}{l}\text { Extreme events (frost, fire, flood, high temperatures) can } \\
\text { be a major determinant of species survival }\end{array}$ & Zimmermann et al. (2009) \\
\hline $\begin{array}{l}\text { Lag effects and gene flow within } \\
\text { species }\end{array}$ & $\begin{array}{l}\text { Species are generally still responding to past changes in } \\
\text { climate and not optimally suited to current conditions }\end{array}$ & $\begin{array}{l}\text { Thuiller et al. (2008), Kuparinen } \\
\text { et al. (2010), Kremer et al. (2012) }\end{array}$ \\
\hline Epigenetic effects & $\begin{array}{l}\text { The growing conditions of the parents can affect the capacity } \\
\text { of progeny to cope with drier or warmer conditions }\end{array}$ & Brautigam et al. (2013) \\
\hline Biotic effects & $\begin{array}{l}\text { Insect pests and diseases can be strong determinants of } \\
\text { species distribution }\end{array}$ & $\begin{array}{l}\text { Anderson et al. (2012), } \\
\text { (Brooker et al. 2007) }\end{array}$ \\
\hline Phenology and life history traits & $\begin{array}{l}\text { Age to sexual maturity, fecundity, seed dispersal, or chilling } \\
\text { or dormancy requirements }\end{array}$ & Nitschke and Innes (2008b) \\
\hline $\begin{array}{l}\text { Mutual benefits with plants } \\
\text { or animals }\end{array}$ & $\begin{array}{l}\text { Some species have strong interactions with other plants, animals } \\
\text { or micro-organisms that may respond differentially to climate }\end{array}$ & Six (2009), Gilman et al. (2012) \\
\hline Competition effects & $\begin{array}{l}\text { SDMs generally assume open-grown conditions. Competition } \\
\text { with other tree species can determine species distribution }\end{array}$ & Castagneri and Motta (2010) \\
\hline
\end{tabular}

Corlett and Westcott (2013) also argued that plant movements are not realistically represented in models used to predict future vegetation or carbon-cycle feedbacks and that fragmentation of natural systems is likely to slow migration rates.

However, these estimates do not account for the role of humans in influencing tree species distributions, which they have done for thousands of years (Clark 2007), and managed translocation may be an option for conserving many tree species, but there are significant unresolved technical and social questions about implementing translocation at a larger scale (Corlett and Westcott 2013).

Most early SDMs relied primarily on temperature envelopes to model future distribution, but factors such as precipitation and soil moisture are potentially more limiting and more important in determining distribution patterns (Dobrowski et al. 2013). Aitken et al. (2008) found that the degree to which variation in precipitation explains phenotypic variation among populations is greater in general for populations from continental than from maritime climates and greater for lower latitude than higher latitude populations. However, precipitation alone is often not a good predictor of variation and there is often a strong interaction with temperature (Andalo et al. 2005). Heat to moisture index or aridity is probably more important in determining future distribution or productivity than precipitation alone (Aitken et al. 2008; Harper et al. 2009; Wang et al. 2012). Soil properties (depth, texture and organic matter content) have a major influence on plant-available water, but few SDMs incorporate these.
Future precipitation is proving more difficult to model than temperature, due to the complex effects of topography, and there are more widely varying estimates between global circulation models (GCMs) of future change in precipitation (IPCC 2013). As such, there is more uncertainty around the extent to which moisture stress will change with warming and the extent to which natural selection pressures will change as a result. Even without changes in precipitation, increased temperatures will increase the length of growing season and potential evapotranspiration (PET) resulting in more water use over the year and greater risk plant water shortage and drought death.

Changes in the intervals of extreme events (extreme heat, cold, precipitation, humidity, wind) may also matter more than changes in the mean. Current forecasting approaches that produce future climate averages may make it difficult to detect non-linear ecosystem dynamics, or threshold effects, that could trigger abrupt ecosystem change (Campbell et al. 2009). Zimmermann et al. (2009) found that predictions of spatial patterns of tree species in Switzerland were improved by incorporating measures of extremes in addition to means in SDMs.

The risks of future climate will also depend on the management goal. If the aim is simply to conserve genetic diversity, risks of extinction or reduction in genetic diversity may be overstated by SDMs because much of the genetic variation within tree species is found within rather than among their populations, and the extinction of a relatively large proportion 
of a population is generally likely to result in relatively little overall loss of genetic diversity (Hamrick 2004). Local habitat heterogeneity (elevation, slope aspect, moisture, etc.) can preserve adaptive genetic variation that, when recombined and exposed to selection in newly colonised habitats, can provide for local adaptation. The longevity of individual trees can also retard population extinction and allow individuals and populations to survive until habitat recovery or because animal and wind pollination can provide levels of pollen flow that are sufficient to counteract the effects of genetic drift in fragmented populations. Consequently, widespread species with large populations, high fecundity and higher levels of phenotypic plasticity are likely to persist and adapt and have an overall greater tolerance to changing climates than predicted by SDMs (Alberto et al. 2013).

Tree species distributions have always been dynamic, responding to changing environmental conditions, and populations are likely to be sub-optimal for their current environments (Namkoong 2001; Wu and Ying 2004). These lag effects are important in predicting species responses to climate change. In a modelling study of Scots pine and silver birch, Kuparinen et al. (2010) predicted that after 100 years of climate change, the genotypic growth period length of both species will lag more than $50 \%$ behind the climatically determined optimum. This lag is reduced by increased mortality of established trees, whereas earlier maturation and higher dispersal ability had comparatively minor effects. Thuiller et al. (2008) suggest that mechanisms for incorporating these 'trailing edge' effects into SDMs are a major area of research potential.

Trees are also capable of long-distance gene flow, which can have both adaptive evolution benefits and disadvantages. Kremer et al. (2012) found that there may be greater positive effects of gene flow for adaptation but that the balance of positive to negative consequences of gene flow differs for leading edge, core and rear sections of forest distributions.

Epigenetics - heritable changes that are not caused by changes in genetic sequences but by differences in the way DNA methylation controls the degree of gene expression-is another complicating factor in determining evolutionary response to climate change (Brautigam et al. 2013). For example, a recent study in Norway spruce (Picea abies) showed that the temperature during embryo development can dramatically affect cold hardiness and bud phenology in the offspring. In some cases, the offspring's phenotype varied by the equivalent of $6^{\circ}$ of latitude from what was expected given the geographic origin of the parents. It remains uncertain whether these traits are persistent, both within an individual's lifetime and in its offspring and subsequent generations (Aitken et al. 2008). It is suggested that analysis of the epigenetic processes in an ecological context, or 'ecological epigenetics', is set to transform our understanding of the way in which organisms function in the landscape. Increased understanding of these processes can inform efforts to manage and breed tree species to help them cope with environmental stresses (Brautigam et al. 2013). Others argue that whilst investigating this evolutionary capacity to adapt is important, understanding responses of species to their changing biotic community is imperative (Anderson et al. 2012) and 'landscape genomics' may offer a better approach for informing management of tree populations under climate change (Sork et al. 2013).

These recent results indicate the importance of accounting for evolutionary processes in forecasts of the future dynamics and productivity of forests. Species experiencing high mortality rates or populations that are subject to regular disturbances such as storms or fires might actually be the quickest to adapt to a warming climate.

Species life history characteristics are also not usually well represented in most climate-based distribution models. Important factors include age to sexual maturity, fecundity, seed dispersal, competition or chilling or dormancy requirements (Nitschke and Innes 2008b).

Competitive relationships within and between species are likely to be altered by climate change. Most models also assume open site growth conditions, rather than those within a forest, where the growth environment will be quite different. However, increased disturbance associated with climate change may create stand reinitiation conditions more often than has occurred in the past, altering competitive interactions.

Process-based models of species range shifts and ecosystem change may capture more of the life history variables and competition effects that will be important in determining responses to climate change (Kimmins 2008; Nitschke and Innes 2008a, b). These can provide the basis for a more robust assessment framework that integrates biological characteristics (e.g. shade tolerance and seedling establishment) and disturbance characteristics (e.g. insect pests, drought and fire topkill). Matthews et al. (2011) integrated these factors into a decision support system that communicates uncertainty inherent in GCM outputs, emissions scenarios and species responses. This demonstrated a greater diversity among species to adapt to climate change and provides a more practical assessment of future species projections.

In summary, whilst SDMs and other climate-based modelling approaches can provide a guide to potential species responses, the extent to which future climate conditions will result in major range shifts or extinction of species is unclear and the value of this approach in adaptation and decision making is limited. The evidence from genetic studies seems to suggest that many species are reasonably robust to potential future climate change. Those with a wide geographic range, large populations and high fecundity may suffer local population extinction but are likely to persist and adapt whilst suffering adaptational lag for a few generations. For example, Booth (2013) considered that many eucalyptus 
species, some of which are widely planted around the world, had a high adaptive capacity even though their natural ranges are quite small.

However, large contractions or shifts in distribution could have significant consequences for different forest values and species with small populations, fragmented ranges, low fecundity or suffering declines due to introduced insects or diseases may have a higher sensitivity and are at greater risk in a changing climate (Aitken et al. 2008).

\subsubsection{Ecosystem responses to climate}

Projecting the fate of forest ecosystems under a changing climate is more challenging than for species. It has been well understood for some time that species will respond individualistically to climate change, rather than moving in concert, and that this is likely to result in 'novel' ecosystems, or groups of species, that are not represented in current classifications (Davis 1986). Forecasts need to consider the importance of these new species interactions and the confounding effects of future human activities.

Climate change affects a wide range of ecosystem functions and processes (Table 2). These include direct effects of temperature and precipitation on physiological and reproductive processes such as photosynthesis, water use, flowering, fruiting and regeneration, growth and mortality and litter decomposition. Changes in these processes will have effects on species attributes such as wood density or foliar nutrient status. Indirect effects will be exhibited through changing fire and other climate-driven disturbances. These will ultimately have impacts on stand composition, habitat structure, timber supply capacity, soil erosion and water yield.

Most early studies of forest ecosystem responses to climate change were built around ecosystem process models at various scales (Graham et al. 1990; Running and Nemani 1991; Rastetter et al. 1991). A number of recent studies have investigated the effects of past and current climate change on forest processes, often with surprising effects (Groffman et al. 2012).

Observed forest growth has increased recently in a number of regions, for example over the last 100 years in Europe (Pretzsch et al. 2014; Kint et al. 2012), and for more recent observations in Amazon forests (Phillips et al. 2008). In a major review, Boisvenue and Running (2006) found that at finer spatial scales, a trend is difficult to decipher, but globally, based on both satellite and ground-based data, climatic changes seemed to have a generally positive impact on forest productivity when water was not limiting. However, there can be a strong difference between species, complicating ecosystem level assessments (Michelot et al. 2012), and there are areas with little observed change (Schwartz et al. 2013). Generally, there are significant challenges in detecting the response of forests to climate change. For example, in the tropics, the lack of historical context, long-term growth
Table 2 Forest ecosystem responses to elevated $\mathrm{CO}_{2}$ and climate change

\begin{tabular}{|c|c|c|}
\hline & Faster response & Slower response \\
\hline Direct & $\begin{array}{l}\text { - Photosynthesis } \\
\text { - Water use/transport } \\
\text { - Flowering/phenology } \\
\text { - Regeneration } \\
\text { - Growth and mortality } \\
\text { - Wood density/quality } \\
\text { - Frost/storm damage }\end{array}$ & $\begin{array}{l}\text { - Litter decomposition } \\
\text { - Foliar nutrient status } \\
\text { - Genetic change } \\
\text { - Tree species distribution and stand } \\
\text { composition }\end{array}$ \\
\hline Indirect & $\begin{array}{l}\text { - Increased fire } \\
\text { frequency/intensity } \\
\text { - Disease impacts } \\
\text { - More insect pests } \\
\text { - Increased invasive } \\
\text { species } \\
\text { - Water quality }\end{array}$ & $\begin{array}{l}\text { - Habitat composition and structure } \\
\text { - Wood supply } \\
\text { - Erosion and soil loss } \\
\text { - Water yield }\end{array}$ \\
\hline
\end{tabular}

records and access to data are real barriers (Clark 2007) and temperate regions also have challenges, even with well-designed, long-term experiments (Leites et al. 2012).

Projections of net primary productivity (NPP) under climate change indicate that there is likely to be a high level of regional variation (Zhao et al. 2013). Using a process model and climate scenario projections, Peters et al. (2013) predicted that average regional productivity in forests in the Great Lakes region of North America could increase from 67 to $142 \%$, runoff could potentially increase from 2 to $22 \%$ and net $\mathrm{N}$ mineralization from 10 to $12 \%$. Increased productivity was almost entirely driven by potential $\mathrm{CO}_{2}$ fertilization effects, rather than by increased temperature or changing precipitation. Productivity in these forests could shift from temperature limited to water limited by the end of the century. Reyer et al. (2014) also found strong regional differences in future NPP in European forests, with potential growth increases in the north but reduced growth in southern Europe, where forests are likely to be more water limited in the future. Again, assumptions about the impact of increasing $\mathrm{CO}_{2}$ were a significant factor in this study.

In a different type of study using analysis of over 2400 long-term measurement plots, Bowman et al. (2014) found that there was a peaked response to temperature in temperate and sub-tropical eucalypt forests, with maximum growth occurring at a mean annual temperature of $11^{\circ} \mathrm{C}$ and maximum temperature of the warmest month of $25-27^{\circ} \mathrm{C}$. Lower temperatures directly constrain growth, whilst high temperatures primarily reduced growth by reducing water availability but they also appeared to exert a direct negative effect. Overall, the productivity of Australia's temperate eucalypt forests could decline substantially as the climate warms, given that $87 \%$ of these forests currently experience a mean annual temperature above the 'optimal' temperature. 
Incorporating the effects of rising $\mathrm{CO}_{2}$ in models of future tree growth continues to be a major challenge. The sensitivity of projected productivity to assumptions regarding increased $\mathrm{CO}_{2}$ was high in modelling studies of climate change impacts in commercial timber plantations in the Southern Hemisphere (Kirschbaum et al. 2012; Battaglia et al. 2009), and a recent analysis indicated a general convergence of different model predictions for future tree species distribution in Europe, with most of the difference between models due to the way in which this effect is incorporated (Cheaib et al. 2012). Increased $\mathrm{CO}_{2}$ has been shown to increase the water-use efficiency of trees, but this is unlikely to entirely offset the effects of increased water stress on tree growth in drying climates (Leuzinger et al. 2011; Booth 2013). In general, despite studies extending over decades and improved understanding of biochemical processes (Franks et al. 2013), the impacts of increased $\mathrm{CO}_{2}$ on tree and stand growth are still unresolved (Kallarackal and Roby 2012).

Integrating process model outputs with spatially explicit landscape models can improve understanding and projection of responses and landscape planning and this could provide for simulations of changes in ecological processes (e.g. tree growth, succession, disturbance cycles, dispersal) with other human-induced changes to landscapes (Campbell et al. 2009).

Investigation of current species responses to changing climate conditions may also guide improved prediction of patterns of future change in ecosystem distribution. For example, Allen et al. (2010) suggest that spatially explicit documentation of environmental conditions in areas of forest die-off is necessary to link mortality to causal climate drivers, including precipitation, temperature and vapour pressure deficit. Better prediction of climate responses will also require improved knowledge of belowground processes and soil moisture conditions. Assessments of future productivity will depend on accurate measurements of rates (net ecosystem exchange and NPP), changes in ecosystem level storage (net ecosystem production) and quantification of disturbances effects to determine net biome production (Boisvenue and Running 2006).

Hydrological conditions, runoff and stream flow are of critical importance for humans and aquatic organisms, and many studies have focused on the implications of climate change for these ecosystem processes. However, most of these have been undertaken at small catchment scale (Mahat and Anderson 2013; Neukum and Azzam 2012; Zhou et al. 2011) with few basin-scale assessments (van Dijk and Keenan 2007). However, the effects of climate and forest cover change on hydrology are complicated. Loss of tree cover may increase stream flow but can also increase evaporation and water loss (Guardiola-Claramonte et al. 2011). The extent of increasing wildfire will also be a major factor determining hydrological responses to climate change (Versini et al. 2013; Feikema et al. 2013).
Changing forest composition will also affect the habitat of vertebrate and invertebrate species. The implications of climate change for biodiversity conservation have been subject to extensive analysis (Garcia et al. 2014; Vihervaara et al. 2013; Schaich and Milad 2013; Clark et al. 2011; Heller and Zavaleta 2009; Miles et al. 2004). An integrated analytical approach, considering both impacts on species and habitat is important. For example, in a study of climate change impacts on bird habitat in the north-eastern USA, the combination of changes in tree distribution and habitat for birds resulted in significant impacts for $60 \%$ of the species. However, the strong association of birds with certain vegetation tempers their response to climate change because localised areas of suitable habitat may persist even after the redistribution of tree species (Matthews et al. 2011).

Understanding thresholds in changing climate conditions that are likely to result in a switch to a different ecosystem state, and the mechanisms that underlie ecosystem responses, will be critical for forest managers (Campbell et al. 2009). Identifying these thresholds of change is challenging. Detailed process-based ecosystem research that identifies and studies critical species interactions and feedback loops, coupled with scenario modelling of future conditions, could provide valuable insights (Kimmins et al. 1999, 2008; Walker and Meyers 2004). Also, rather than pushing systems across thresholds into alternative states, climate change may create a stepwise progression to unknown transitional states that track changing climate conditions, requiring a more graduated approach in management decisions (Lin and Petersen 2013).

Ultimately, management decisions may not be driven by whether we can determine future thresholds of change, but by observing the stressors that determine physiological limits of species distributions. These thresholds will depend on species physiology and local site conditions, with recent research demonstrating already observed ecosystem responses to climate change, including die-back of some species (Allen et al. 2010; Rigling et al. 2013).

\subsubsection{Fire, pests, invasive species and disturbance risks}

Many of the impacts of a changing future climate are likely to be felt through changing disturbance regimes, in particular fire. Forest fire weather risk and fire behaviour prediction have been two areas where there has been strong historical interaction between climate science and forest management and where we may see major tipping points driving change in ecosystem composition (Adams 2013). Fire weather is fundamentally under the control of large-scale climate conditions with antecedent moisture anomalies and large-scale atmospheric circulation patterns, further exacerbated by configuration of local winds, driving fire weather (Brotak and Reifsnyder 1977; Westerling et al. 2002, 2006). It is therefore important to improve understanding of both short- and long- 
term atmospheric conditions in determining meteorological fire risk (Amraoui et al. 2013).

Increased fuel loads and changes to forest structure due to long periods of fire exclusion and suppression are increasing fire intensity and limiting capacity to control fires under severe conditions (Williams 2004, 2013). Increasing urbanisation is increasing the interface between urban populations and forests in high fire risk regions, resulting in greater impacts of wildfire on human populations, infrastructure and assets (Williams 2004). Deforestation and burning of debris and other types of human activities are also introducing fire in areas where it was historically relatively rare (Tacconi et al. 2007).

In a recent study, Chuvieco et al. (2014) assessed ecosystem vulnerability to fire using an index based on ecological richness and fragility, provision of ecosystem services and value of houses in the wildland-urban interface. The most vulnerable areas were found to be the rainforests of the Amazon Basin, Central Africa and Southeast Asia; the temperate forest of Europe, South America and north-east America; and the ecological corridors of Central America and Southeast Asia.

In general, fire management policies in many parts of the world will need to cope with longer and more severe fire seasons, increasing fire frequency, and larger areas exposed to fire risk. This will especially be the case in the Mediterranean region of Europe (Kolström et al. 2011) and other fireprone parts of the world such as South Eastern Australia (Hennessy et al. 2005). This will require improved approaches to fire weather modelling and behaviour prediction that integrate a more sophisticated understanding of the climate system with local knowledge of topography, vegetation and wind patterns. It will also require the development of fire management capacity where it had previously not been necessary. Increased fire weather severity could push current suppression capacity beyond a tipping point, resulting in a substantial increase in large fires (de Groot et al. 2013; Liu et al. 2010) and increased investment in resources and management efforts for disaster prevention and recovery.

Biotic factors may be more important than direct climate effects on tree populations in a changing climate. For example, insects and diseases have much shorter generation length and are able to adapt to new climatic conditions more rapidly than trees. However, if insects move more rapidly to a new environment whilst tree species lag, some parts of the tree population may be impacted less in the future (Regniere 2009).

The interaction of pests, diseases and fire will also be important. For example, this interaction will potentially determine the vulnerability of western white pine (Pinus monticola) ecosystems in Montana in the USA. Loehman et al. (2011) found that warmer temperatures will favour western white pine over existing climax and shade tolerant species, mainly because warmer conditions will lead to increased frequency and extent of wildfires that facilitates regeneration of this species.

\subsection{Adaptation actions in forest management}

The large majority of published studies relating to forests and climate change have been on vulnerability and impacts. These have increased understanding of the various relationships between forest ecosystems and climate and improved capacity to predict and assess ecosystem responses. However, managers need greater guidance in anticipating and responding to potential impacts of climate change and methods to determine the efficiency and efficacy of different management responses because they are generally not responding sufficiently to potential climate risks.

\subsubsection{Adaptation actions at different management levels}

A number of recent reviews have described adaptation actions and their potential application in different forest ecosystems being managed for different types of goods or services (Bernier and Schöne 2009; Innes et al. 2009; Lindner et al. 2010; Kolström et al. 2011), and adaptation guides and manuals have been developed (Peterson et al. 2011; Stephens et al. 2012) for different types of forest and jurisdictions. Adaptation actions can be primarily aimed at reducing vulnerability to increasing threats or shocks from natural disasters or extreme events, or increasing resilience and capacity to respond to progressive change or climate extremes. Adaptation actions can be reactive to changing conditions or planned interventions that anticipate future change. They may involve incremental changes to existing management systems or longer term transformational changes (Stafford Smith et al. 2011). Adaptation actions can also be applied at the stand level or at ownership, estate or national scales (Keskitalo 2011).

Recent research at the stand level in forests in the SE USA showed that forest thinning, often recommended in systems that are likely to experience increased temperature and decreased precipitation as a result of climate change, will need to be more aggressive than traditionally practised to stimulate growth of large residual trees, improve drought resistance and provide greater resilience to future climate-related stress (Kerhoulas et al. 2013).

An analysis of three multi-aged stand-level options in Nova Scotia, Canada, Steenberg et al. (2011) found that leaving sexually immature trees to build stand complexity had the most benefit for timber supply but was least effective in promoting resistance to climate change at the prescribed harvest intensity. Varying the species composition of harvested trees proved the most effective treatment for maximising forest age and old-growth area and for promoting stands composed of climatically suited target species. The combination of all three treatments resulted in an adequate 
representation of target species and old forest without overly diminishing the timber supply and was considered most effective in minimising the trade-offs between management values and objectives.

An estate level analysis of Austrian Federal Forests indicated that management to promote mixed stands of species that are likely to be well adapted to emerging environmental conditions, silvicultural techniques fostering complexity and increased management intensity might successfully reduce vulnerability, with the timing of adaptation measures important to sustain supply of forest goods and services (Seidl et al. 2011).

Whilst researchers are analysing different management options, the extent to which they are being implemented in practice is generally limited. For example, in four regions in Germany, strategies for adapting forest management to climate change are in the early stages of development or simply supplement existing strategies relating to general risk reduction or to introduce more 'nature-orientated' forest management (Milad et al. 2013). Guariguata et al. (2012) found that forest managers across the tropics perceived that natural and planted forests are at risk from climate change but were ambivalent about the value of investing in adaptation measures, with climate-related threats to forests ranked below others such as clearing for commercial agriculture and unplanned logging.

Community-based management approaches are often argued to be the most successful approach for adaptation. An analysis of 38 community forestry organisations in British Columbia found that $45 \%$ were researching adaptation and $32 \%$ were integrating adaptation techniques into their work (Furness and Nelson 2012). Whilst these community forest managers appreciated support and advice from government for adaptation, balancing this advice with autonomy for communities to make their own decisions was considered challenging.

In a study of communities impacted by drought in the forest zone of Cameroon, Bele et al. (2013b) identified adaptive strategies such as community-created firebreaks to protect their forests and farms from forest fires, the culture of maize and other vegetables in dried swamps, diversifying income activities or changing food regimes. However, these coping strategies were considered to be incommensurate with the rate and magnitude of change being experienced and therefore no longer seen as useful. Some adaptive actions, whilst effective, were resource inefficient and potentially translate pressure from one sector to another or generated other secondary effects that made them undesirable.

\subsubsection{Integrating adaptation and mitigation}

In considering responses to climate change, forest managers will generally be looking for solutions that address both mitigation objectives and adaptation. To maintain or increase forest carbon stocks over the long term, the two are obviously inextricably linked (Innes et al. 2009). Whilst there are potentially strong synergies, Locatelli et al. (2011) identified potential trade-offs between actions to address mitigation and the provision of local ecosystem services and those for adaptation. They argued that mitigation projects can facilitate or hinder the adaptation of local people to climate change, whereas adaptation projects can affect ecosystems and their potential to sequester carbon.

Broadly, there has been little integration to date of mitigation and adaptation objectives in climate policy. For example, there is little connection between policies supporting the reducing emissions from deforestation and forest degradation plus (REDD+) initiatives and adaptation. Integrating adaptation into REDD + can advance climate change mitigation goals and objectives for sustainable forest management (Long 2013). Kant and Wu (2012) considered that adaptation actions in tropical forests (protection against fire and disease, ensuring adequate regeneration and protecting against coastal impacts and desertification) will improve future forest resilience and have significant climate change mitigation value.

\subsubsection{Sector-level adaptation}

Analyses of climate change impacts and vulnerability at the sector level have been undertaken for some time (Lindner et al. 2002; Johnston and Williamson 2007; Joyce 2007). However, it has recently been argued (Wellstead et al. 2014) that these assessments, which focus on macro system-level variables and relationships, fail to account for the multi-level or polycentric nature of governance and the possibility that policy processes may result in the non-performance of critical tasks required for adaptation.

Joyce et al. (2009) considered that a toolbox of management options for the US National Forests would include the following: practices focused on reducing future climate change effects by building resistance and resilience into current ecosystems and on managing for change by enabling plants, animals and ecosystems to adapt to climate change. Sample et al. (2014) demonstrated the utility of this approach in a coniferous forest management unit in northwestern USA. It provided an effective means for guiding management decisions and an empirical basis for setting budgetary and management priorities. In general, more widespread implementation of already known practices that reduce the impact of existing stressors represents an important 'no regrets' strategy.

Johnston and Hesseln (2012) found that barriers to implementing adaptation across forest sector managers in Canada included inflexible tenure arrangements and regulatory environments which do not support innovation. Echoing calls for wider implementation of SFM as a key adaptation strategy (Innes et al. 2009), they argued that forest certification systems, participating in the Canadian model forest 
programme, and adopting criteria and indicators of SFM can support sectoral level adaptation.

Decentralised management approaches are considered to be a more appropriate governance arrangement for forest management, but Rayner et al. (2013) argued that a decentralised forest policy sector in Canada has resulted in limitations where policy, such as adaptation, requires a coherent national response. Climate change adaptation has led to an expansion of departmental mandates that is not being addressed by better coordination of the available policy capacity. Relevant federal agencies are not well represented in information networks, and forest policy workers report lower levels of internal and external networking than workers in related policy subsectors.

Economic diversification can be a valuable strategy to improve resilience to climate-related shocks. This can take a range of forms: developing new industries or different types of forest-based industries based on different goods or services. For the timber sector, the value of diversification as a risk management strategy for communities is open to question. Ince et al. (2011) pointed out that the forest sector operates in an international market and is susceptible to changes in the structure of this market. In the US forest sector, globalization has accelerated structural change, favouring larger and more capital-intensive enterprises and altering historical patterns of resource use. They suggest that future markets for timber will be driven by developments in these larger scale enterprises and may not lead to expansion of opportunities for smaller scale forest enterprises because development of niche markets or customised products is likely to be pursued aggressively by larger globally oriented enterprises to develop branding, product identity and product value. How to best diversify for adaptation therefore remains an open question.

Consequently, whilst policies that support economic diversification will be important, this may involve diversification well beyond traditional sectors. For example, in areas where there is a high probability that forests will be lost in favour of other ecosystems, such as grasslands, managers should recognise early on that their efforts and resources may best be focused outside forests (Innes et al. 2009). These adjustments will involve taking into account the perceptions of climate risk by various stakeholders, including individuals, communities, governments, private institutions and organisations (Adger et al. 2007). Vulnerability assessments and adaptation measures also need to be developed in a framework that takes into account the vulnerabilities and actions in other sectors that are linked to the forest sector, such as food, energy, health and water (Sonwa et al. 2012).

\subsection{New approaches to decision making}

Climate change presents new challenges for forest managers. Change is likely to happen faster than traditional, empirical approaches can provide evidence to support changes in management. Uncertainties in a range of aspects of future climate may also not be reduced through investment in research. Given that management for activities such as timber production can no longer be based solely on empirically derived growth and yield trajectories and management plans must incorporate uncertainty and the increased probability of extreme events, what types of tools are available to support these approaches? This section presents key points from the literature on decision making under uncertainty, adaptive management and resilience as a guide to future decision making in forest management.

\subsubsection{Decision making under uncertainty}

The future conditions for forest managers are subject to a high degree of uncertainty, and the future prospects for reducing these large uncertainties are limited. There is uncertainty regarding the trajectory of future increases in atmospheric greenhouse gases, what kind of effects these might have on the climate system and the effects of climatic changes on ecological and social systems and their capacity to adapt (see Fig. 2) (Wilby and Dessai 2010).

Consequently, many forest managers consider that the future situation is too uncertain to support long-term and potentially costly decisions that may be difficult to reverse. Dessai and Hulme (2004) argued that uncertainty per se should not be a reason for inaction. However, the critical issue for managers is deciding the types of actions to take and the timing and conditions under which they should be taken (Ogden and Innes 2007a). A more reactive 'wait and see' approach (or 'purposeful procrastination') might be justified if uncertainty or costs are high relative to the expected impacts and risks, or if it is cheaper to implement interventions by waiting until after a significant disturbance (e.g. replanting an area with more fire- or drought-resistant tree species after a wildfire or drought-induced insect outbreak).

Effective adaptation requires setting clear objectives. Managers and policy makers need to decide whether they are trying to facilitate ecosystem adaptation through changing species composition or forest structure or trying to engineer resistance to change through proactive management strategies (Joyce et al. 2008). Establishing objectives often depends on the integration of the preferences of different stakeholders (Prato 2008), but changing social preferences presents another source of potential uncertainty.

Risk assessment and management provide a foundation for decision making in considering climate change in natural resource management. This approach provides both a qualitative and quantitative framework for evaluating climate change effects and adaptation options. Incorporating risk management approaches into forest management plans can provide 
Fig. 2 The cascade of uncertainty (Wilby and Dessai 2010)
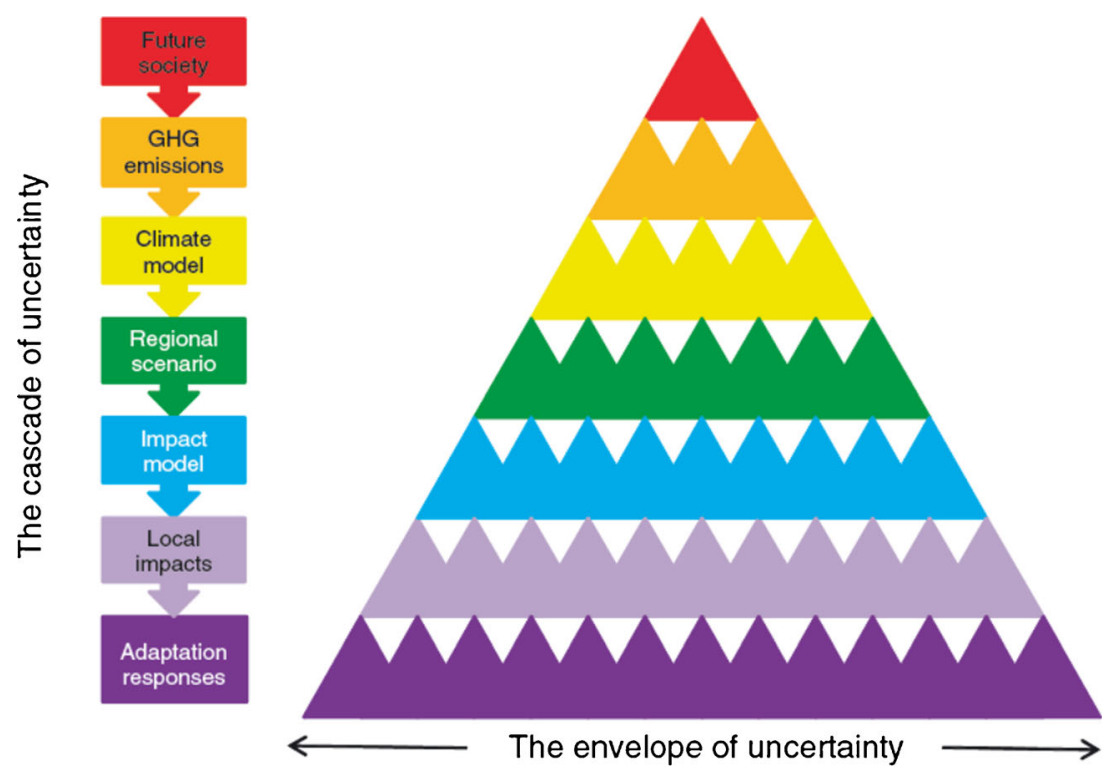

a basis for managers to continue to provide forest conditions that meet a range of important values (Day and Perez 2013).

However, risk approaches generally requiring assigning probabilities to future events. In a comprehensive review, Yousefpour et al. (2011) identified a growing body of research literature on decision making under uncertainty, much of which has focused on price uncertainty and variation in timber production but is extending to multiple forest management objectives and other types of risk. They argue that we are actually in a stochastic transition from one known stable (but variable) climate state to a new but largely unknown and likely more rapidly changing set of future conditions.

Decision makers themselves may also not be the rational actors assumed by these models, with their decisions taken according to quite different assumptions, preferences and beliefs (Ananda and Herath 2009; Couture and Reynaud 2008). Therefore, the communication approach will be important in determining whether the information is acted on. In a recent study, Yousefpour et al. (2014) considered that the speed with which decision makers will form firm beliefs about future climate depends on the divergence among climate trajectories, the speed of change and short-term climate variability. Using a Bayesian modelling approach, they found that if a large change in climate occurs, the value of investing in knowledge and taking an adaptive approach would be positive and higher than a non-adaptive approach. In communicating about uncertainty, it may be better to focus discussion on the varying time in the future when things will happen, rather than on whether they will happen at all (Lindner et al. 2014).

Increased investment in climate science and projections or species distribution modelling may not necessarily decrease uncertainty in climate projections or impacts. Climate models are best viewed as heuristic tools rather than as accurate forecasts of the future (Innes et al. 2009). Trajectories of change in many other drivers of forest management (social, political or economic) are also highly uncertain (Keskitalo 2008) and the effects of these on the projected performance of management can be the same order of magnitude, requiring an integrated social-ecological perspective to adaptation (Seidl and Lexer 2013).

In a more 'decision-centred' approach, plausible scenarios of the potential range of future conditions are required. These can be derived from climate models but do not need to be accurate and precise 'predictions' of future climate states (Wilby and Dessai 2010). To support this type of approach, research needs to focus on improved understanding of tree and ecosystem responses and identifying those aspects of climate to which different forest types are most sensitive.

Devising strategies that are able to meet management objectives under a range of future scenarios is likely to be the most robust approach, recognising that these strategies are unlikely to be optimal under all future conditions. In some cases, the effect of different scenarios on forest growth may not be that great and differences in the present value of different management options are relatively small. For example, Eriksson et al. (2011) found that there was limited benefit in attempting to optimise management plans in accordance with future temperature scenarios.

Integration of climate change science and adaptation in forest management planning is considered important for building resilience in forest social and ecological systems (Keskitalo 2011; D'Amato et al. 2011; Chmura et al. 2011; Parks and Bernier 2010; Lindner et al. 2014). Forest restoration is becoming a more prominent aspect of forest management in many parts of the world and restoration approaches will also need to integrate understanding of future climate change to be successful (Stanturf et al. 2014). 


\subsubsection{Adaptive management, resilience and decisions}

Adaptive management provides a mechanism to move forward when faced with future uncertainty (Innes et al. 2009). It can be viewed as a systematic process for continually improving management policies and practices by monitoring and then learning from the outcomes of operational programmes as a basis for incorporating adaptation actions into forest management. Whilst many management initiatives purport to implement these principles, they often lack essential characteristics of the approach (Innes et al. 2009).

However, effective adaptation to changing climate cannot simply involve adaptive management as it is currently understood. The pace of climate change is not likely to allow for the use of management as a tool to learn about the system by implementing methodologies to test hypotheses concerning known uncertainties (Holling 1978). Future climatic conditions may result in system states and dynamics that have never previously existed (Stainforth et al. 2007), so observation of past experience may be a poor guide for future action. Management will need to be more 'forward-looking', considering the range of possible future conditions and planning actions that consider that full range.

How does this translate into the practical guidance forest managers are seeking on how to adapt their current practices and, if necessary, their goals (Blate et al. 2009)? Managers will need to consider trade-offs between different objectives under different conditions. For example, Seidl et al. (2011) showed that, to keep climate vulnerability in an Austrian forest low, Norway spruce will have to be replaced almost entirely by better adapted species. However, indicator weights that favoured timber production over $\mathrm{C}$ storage or biodiversity exerted a strong influence on the results. Wider social implications of imposing such drastic changes in forest landscapes will also deserve stronger consideration in decision making.

Ecosystem management will need to be reframed to accommodate the risks of a changing climate. Adaptive strategies, even without specific information on the future climate conditions of a target ecosystem, would enhance social and ecological resilience to address the uncertainties due to changing climate (Mori et al. 2013). These are likely to be more subject to change over the short to medium term, in response to more rapidly changing conditions.

Analysis of ecosystem resilience can provide a framework for these assessments. Resilience can be defined as 'the capacity of ecosystems to absorb disturbance and reorganise so as to retain essentially the same function, structure and feedbacks - to have the same identity' (Walker and Salt 2012). It is a function of the capacity of an ecosystem to resist change, the extent and pace of change and the ability of an ecosystem to reorganise following disturbance. The concept of resilience holds promise for informing future forest management, but Rist and Moen (2013) argue that its contributions are, so far, largely conceptual and offer more in terms of being a problemframing approach than analytical or practical tools. There may also be trade-offs involved with focusing on resilience through retention of current species composition or using a more adaptation-oriented management approach after disturbances (Buma and Wessman 2013). Complexity theory and concepts can provide an appropriate framework for managing resilience (Messier et al. 2013).

Management decisions will ultimately depend on the costs and benefits of different options, but there are few examples of decision making frameworks that compare the costs of future impacts with the costs of different actions and the efficacy of those actions in reducing impacts. Ogden and Innes (2009) used a structured decision making process to identify and assess 24 adaptation options that managers considered important to achieve their regional goals and objectives of sustainable forest management in light of climate change. In the analysis of options for biodiversity conservation, Wintle et al. (2011) found that the amount of funding available for adaptation was a critical factor in deciding options aimed at minimising species extinctions in the mega-diverse fynbos biome of South Africa. When the available budget is small, fire management was the best strategy. If the budget is increased to an intermediate level, the marginal returns from more fire management were limited and the best strategy was added habitat protection. Above another budget threshold, increased investment should go into more fire management. By integrating ecological predictions in an economic decision framework, they found that making the choice of how much to invest is as important as determining what actions to take.

\subsubsection{Adaptation as a social learning process}

Whilst adaptation has been defined as 'adjustment in natural or human systems in response to actual or expected climatic stimuli or their effects' (Levina and Tirpak 2006), adaptation is essentially about meeting future human needs (Spittlehouse and Stewart 2003; Hahn and Knoke 2010). Consequently, it is inherently a social process. Forest landscapes are socialecological systems that involve both nature and society (Innes et al. 2009), and resolving trade-offs between different management objectives to meet the different needs in society is an important element of sustainable forest management. As Kolström et al. (2011) pointed out, some proposed adaptation measures may change the balance between current objectives and stakeholder interests, and it will be important to consider the relative balance of different measures at the stand, management unit and landscape scales.

Those investigating adaptive management also recognise that it goes beyond the focus on scientific methods, statistical designs or analytical rigour favoured by its early proponents and that there is now an expectation of much greater stakeholder involvement, with the concept being renamed by some 
as adaptive, collaborative management (Innes et al. 2009). SFM and adaptation are as much about those who inhabit, work in or utilise forests as it is about managing the forest ecosystems themselves (White et al. 2010; Pramova et al. 2012; Fischer et al. 2013).

The choice of adaptation options will thus likely be relatively complex, even in cases where information and policy have been developed, and communication measures for forest management have been well formulated. Making such choices may require considerable knowledge, competence and commitment for implementation at the local level (Keskitalo 2011). Effective adaptation will require much greater cooperation between stakeholders, more flexibility for management actions and commitment of time to develop the social license for action in the absence of conclusive evidence or understanding. This will require venues for sharing perspectives on the nature of the problem (Fig. 3).

\subsubsection{Local and indigenous knowledge}

The promotion of community-based forest management may increase local adaptive capacity by putting decisions in the hands of those people who first feel the effects of climate change (Gyampoh et al. 2009). In this context, local knowledge systems based on long-term observation and experience are likely to be of increasing importance in decision making. Adaptation strategies can benefit from combining scientific and indigenous knowledge, especially in developing countries (Gyampoh et al. 2009), with the translation of local forest knowledge into the language of formal forest science being considered an important step towards adaptation (Roberts et al. 2009). However, conservation and natural resource managers in government agencies have often discounted traditional local management systems (Scott 2005), although Spathelf et al. (2014) provided a useful approach for capturing local expert knowledge. Linking this type of knowledge with broader scientific understanding of ecosystem functioning and the global climate system will be a major challenge, requiring consideration of both technical and cultural issues (Caverley 2013), including intellectual property concerns of indigenous people (Lynch et al. 2010).

\subsection{Policy arrangements for adaptation}

Increasingly, many are arguing that effectively responding to climate change will require polycentric and multi-level governance arrangements (Peel et al. 2012). However, Nilsson et al. (2012) found that institutionalising of knowledge and knowledge exchange regarding climate change adaptation in Sweden was weak and that improved mechanisms are required for feedback from the local to the national level. Recent studies have described stronger relationships between scientific research and forest management to assess trade-offs and

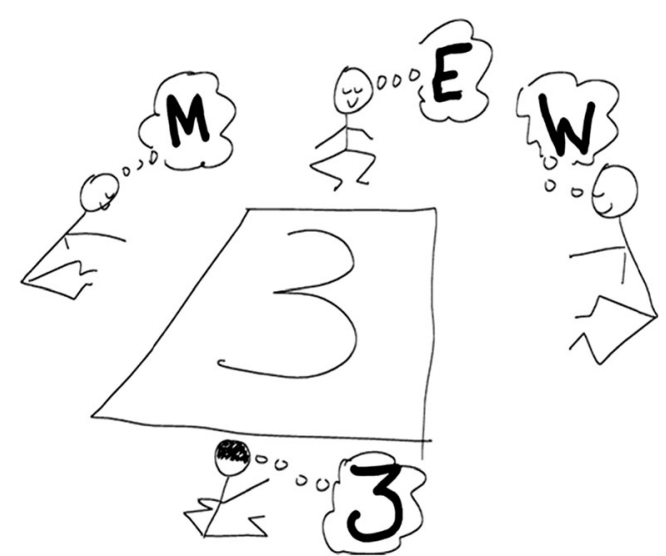

Fig. 3 Adaptation as a social learning process. There is a need to provide situations to share different viewpoints on the nature of the problem as a basis for developing shared solutions (image source: John Rowley, http:// ch301.cm.utexas.edu/learn/)

synergies, for participatory decision making and for shared learning (Blate et al. 2009; Littell et al. 2012; Klenk et al. 2011).

Many papers emphasised the need for greater flexibility in the policies, cultures and structures of forest management organisations (Brown 2009; von Detten and Faber 2013; Rayner et al. 2013). Because no single community or agency can prepare on their own for future impacts, inter-sectoral policy coordination will be required to ensure that policy developments in related policy sectors are not contradictory or counterproductive. Greater integration of information, knowledge and experience and collaborative projects involving scientists, practitioners and policy makers from multiple policy communities could increase focus on resilience, identify regions of large-scale vulnerability and provide a more rigorous framework for the analysis of vulnerability and adaptation actions (Thomalla et al. 2006).

There is also likely to be a greater need for cross-border implementation of different forest management options, requiring greater coordination between nation states and subnational governments (Keenan 2012). Policy is the product of both 'top-down' and 'bottom-up' processes and these might sometimes be in conflict. Simply having 'good policy' in place is unlikely to be sufficient, as a great deal of what takes place at 'street level' is not determined by formal aims of central policy (Urwin and Jordan 2008). Having the right policies can send a strong political signal that adaptation needs to be considered seriously but flexibility in policy systems will be required to facilitate adaptive planning.

\section{Discussion and conclusions}

This broad survey of the literature indicated that, whilst there has been considerable development in research and thinking 
about adaptation in forest management over the last 10 years, research is still strongly focused on assessment of future impacts, responses and vulnerability of species and ecosystems (and in some cases communities and forest industries) to climate change. There has been some movement from a static view of climate based on long-term averages to a more detailed understanding of the drivers of different climate systems and how these affect the factors of greatest influence on different forest ecosystems processes, such as variability and extremes in temperature or precipitation or fire disturbance. For example, Guan et al. (2012) demonstrated that quasiperiodic climate variation on an inter-annual (ENSO) to inter-decadal (PDO) time scale can significantly influence tree growth and should be taken into account when assessing the impact of climate changes on forest productivity.

Adaptation is, in essence, about making good decisions for the future, taking into account the implications of climate change. It involves recognising and understanding potential future climate impacts and planning and managing for their consequences, whilst also considering the broader social, economic or other environmental changes that may impact on us, individually or collectively. To effectively provide a role in mitigation, delivering associated ecosystem services and benefits in poverty reduction (Eliasch 2008) forest management will have to adapt to a changing and highly variable climate. In achieving this, the roles and responsibilities of different levels of government, the private sector and different parts of the community are still being defined.

The broader literature emphasises that adaptation is a continuous process, involving a process of 'adapting well' to continuously changing conditions (Tompkins et al. 2010). This requires organisational learning based on past experience, new knowledge and a comprehensive analysis of future options. This can take place through 'learning by doing' or through a process of search and planned modification of routines (Berkhout et al. 2006). However, interpreting climate signals is not easy for organisations, the evidence of change is ambiguous and the stimuli are not often experienced directly within the organisation. For example, many forest managers in Australia currently feel little need to change practices to adapt to climate change, given both weak policy signals and limited perceived immediate evidence of increasing climate impacts (Cockfield et al. 2011). To explain and predict adaptation to climate change, the combination of personal experience and beliefs must be considered (Blennow et al. 2012). 'Climate smart' forest management frameworks can provide an improved basis for managing forested landscapes and maintaining ecosystem health and vitality based on an understanding of landscape vulnerability to future climatic change (Fig. 4) (Nitschke and Innes 2008a).

Many are now asking, do we really need more research to start adapting forest management to climate change? Whilst adaptation is often considered 'knowledge deficit' problem- where scientists provide more information and forest managers will automatically make better decisions - the reality is that the way in which this information is presented and how it is interpreted and received, will play major roles in determining potential responses. Successful adaptation will require dissemination of knowledge of potential climate impacts and suitable adaptation measures to decision makers at both practice and policy levels (Kolström et al. 2011) but it needs to go well beyond that.

Adaptation is, above all, a social learning process. It requires an understanding of sense of place, a capacity for individuals and society to consider potential future changes and what they mean for their circumstances. Leaders in forest management organisations will need to support a greater diversity of inputs into decision making, avoid creating rigid organisational hierarchies that deter innovation, and be inclusive, open and questioning (Konkin and Hopkins 2009). They will need to create more opportunities for interaction between researchers, managers and the community and space for reflection on the implications and the outcomes of management actions and unplanned events. Researchers will need to develop new modes of communication, providing knowledge in forms that are appropriate to the management decision and suitable for digestion by a range of different audiences.

From this analysis, key gaps in knowledge for adaptation may not be improved climate scenarios or better understanding of the biophysical responses of individual tree species or forest ecosystems to future climate. Knowledge gaps lie more in understanding the social and community attitudes and values that drive forest management and the decision making processes of forest managers, in order to work out how 'climate intelligence' can be built in to these processes.

The impacts of changing climate will vary locally. Consequently, managers must be given the flexibility to respond in ways that meet their particular needs and capacity to choose

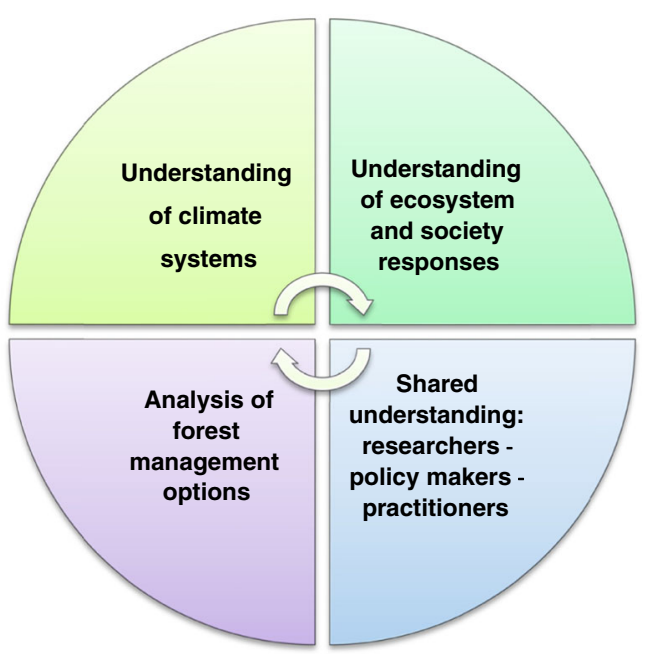

Fig. 4 Components of climate smart forest management (after Nitschke and Innes 2008a, b) 
management options that are applicable to the local situation (Innes et al. 2009). This may not be consistent with rigid indicator-driven management assessment processes like forest certification. Whilst policy to support climate change mitigation is primarily a task for national governments and international agreements and processes, responsibility for supporting adaptation will fall more to sub-national and local governments, communities and the private sector. More active management will be required if specific values are to be maintained, particularly for forests in conservation reserves. This will require additional investment, but there has been little analysis to support the business case for investment in adaptation or to determine who should pay, particularly in developing countries.

We need to strengthen the relationship between climate science, forest research, forest managers and the community. Key challenges will include the setting of objectives for desired future conditions and accepting that we may not be able to maintain everything that forests have traditionally provided. It is important to discuss and agree on common goals in order to cope with, or benefit from, the challenges of future climates. Actively managing our forest ecosystems effectively and intelligently, using the best available knowledge and foresight capacity, can make those goals a reality.

Acknowledgments Thanks to Linda Joyce for her comments on an earlier draft of this paper, to a number of anonymous reviewers for their thoughtful suggestions and to many colleagues that I have discussed these ideas with over the past five years.

Open Access This article is distributed under the terms of the Creative Commons Attribution License which permits any use, distribution, and reproduction in any medium, provided the original author(s) and the source are credited.

\section{References}

Adams MA (2013) Mega-fires, tipping points and ecosystem services: managing forests and woodlands in an uncertain future. For Ecol Manag 294:250-261. doi:10.1016/j.foreco.2012.11.039

Adger WN, Agrawala S, Mirza MMQ, Conde C, O'Brien K, Pulhin J, Pulwarty R, Smit B, Takahashi K (2007) Assessment of adaptation practices, options, constraints and capacity. In: Parry ML, Canziani OF, Palutikof JP, van der Linden PJ, Hanson CE (eds) Climate change 2007: impacts, adaptation and vulnerability. Contribution of Working Group II to the Fourth Assessment Report of the Intergovernmental Panel of Climate Change (IPCC). Cambridge University Press, Cambridge, pp 717-743

Aitken SN, Yeaman S, Holliday JA, Wang T, Curtis-McLane S (2008) Adaptation, migration or extirpation: climate change outcomes for tree populations. Evol Appl 1:95-111. doi:10.1111/j.1752-4571. 2007.00013.x

Alberto FJ, Aitken SN, Alia R, Gonzalez-Martinez SC, Hanninen H, Kremer A, Lefevre F, Lenormand T, Yeaman S, Whetten R, Savolainen O (2013) Potential for evolutionary responses to climate change evidence from tree populations. Glob Chang Biol 19:16451661. doi: $10.1111 / \mathrm{gcb} .12181$
Allen CD, Macalady AK, Chenchouni H, Bachelet D, McDowell N, Vennetier M, Kitzberger T, Rigling A, Breshears DD, Hogg EH, Gonzalez P, Fensham R, Zhang Z, Castro J, Demidova N, Lim J-H, Allard G, Running SW, Semerci A, Cobb N (2010) A global overview of drought and heat-induced tree mortality reveals emerging climate change risks for forests. For Ecol Manag 259:660-684. doi:10.1016/j.foreco.2009.09.001

Amraoui M, Liberato MLR, Calado TJ, DaCamara CC, Coelho LP, Trigo RM, Gouveia CM (2013) Fire activity over Mediterranean Europe based on information from Meteosat-8. For Ecol Manag 294:62-75. doi: $10.1016 /$ j.foreco.2012.08.032

Ananda J, Herath G (2009) A critical review of multi-criteria decision making methods with special reference to forest management and planning. Ecol Econ 68:2535-2548. doi:10.1016/j.ecolecon.2009. 05.010

Andalo C, Beaulieu J, Bousquet J (2005) The impact of climate change on growth of local white spruce populations in Québec, Canada. For Ecol Manag 205:169-182. doi:10.1016/j.foreco.2004.10.045

Anderson JM (1991) The effects of climate change on decomposition processes in grassland and coniferous forests. Ecol Appl 1:326-347. doi: $10.2307 / 1941761$

Anderson JT, Panetta AM, Mitchell-Olds T (2012) Evolutionary and ecological responses to anthropogenic climate change. Plant Physiol 160:1728-1740. doi:10.1104/pp. 112.206219

Attorre F, Francesconi F, Scarnati L, De Sanctis M, Alfo M, Bruno F (2008) Predicting the effect of climate change on tree species abundance and distribution at a regional scale. For Biogeosci For 1:132 139. doi:10.3832/ifor0467-0010132

Battaglia M, Bruce J, Brack C, Baker T (2009) Climate change and Australia's plantation estate: analysis of vulnerability and preliminary investigation of adaptation options.

Battaglia M, Sands P, White D, Mummery D (2004) CABALA: a linked carbon, water and nitrogen model of forest growth for silvicultural decision support. For Ecol Manag 193:251-282

Bele MY, Sonwa DJ, Tiani AM (2013a) Supporting local adaptive capacity to climate change in the Congo basin forest of Cameroon a participatory action research approach. Int J Clim Chang Strateg Manag 5:181-197. doi:10.1108/17568691311327587

Bele MY, Tiani AM, Somorin OA, Sonwa DJ (2013b) Exploring vulnerability and adaptation to climate change of communities in the forest zone of Cameroon. Clim Chang 119:875-889. doi:10.1007/s10584013-0738-z

Berkhout F, Hertin J, Gann D (2006) Learning to adapt: organisational adaptation to climate change impacts. Clim Chang 78:135-156. doi: 10.1007/s10584-006-9089-3

Bernier P, Schöne D (2009) Adapting forests and their management to climate change: an overview. Unasylva 60:5-11

Blate GM, Joyce LA, Littell JS, McNulty SG, Millar CI, Moser SC, Neilson RP, O'Halloran K, Peterson DL (2009) Adapting to climate change in United States national forests. Unasylva 60:57-62

Blennow K, Persson J, Tome M, Hanewinkel M (2012) Climate change: believing and seeing implies adapting. PLoS ONE 7:e50182. doi:10. 1371/journal.pone.0050182

Boisvenue C, Running SW (2006) Impacts of climate change on natural forest productivity - evidence since the middle of the 20th century. Glob Chang Biol 12:862-882. doi:10.1111/j.1365-2486.2006. 01134.x

Bolte A, Eisenhauer DR, Ehrhart HP, Gross J, Hanewinkel M, Kolling C, Profft I, Rohde M, Rohe P, Amereller K (2009) Climate change and forest management-accordances and differences between the German states regarding assessments for needs and strategies towards forest adaptation. Landbauforschung Volkenrode 59:269-278

Bonan GB, Pollard D, Thompson SL (1992) Effects of boreal forest vegetation on global climate. Nature 359:716-718. doi:10.1038/ $359716 \mathrm{a} 0$ 
Bongers F, Poorter L, Van Rompaey R, Parren MPE (1999) Distribution of twelve moist forest canopy tree species in Liberia and Cote d'Ivoire: response curves to a climatic gradient. J Veg Sci 10:371382. doi: $10.2307 / 3237066$

Booth TH (1990) Mapping regions climatically suitable for particular tree species at the global scale. For Ecol Manag 36:47-60

Booth TH (2013) Eucalypt plantations and climate change. For Ecol Manag 301:28-34. doi:10.1016/j.foreco.2012.04.004

Booth TH, Nix HA, Hutchinson MF, Jovanovic T (1988) Niche analysis and tree species introduction. For Ecol Manag 23:47-59

Bowman DMJS, Williamson GJ, Keenan RJ, Prior LD (2014) A warmer world will reduce tree growth in evergreen broadleaf forests: evidence from Australian temperate and subtropical eucalypt forests. Glob Ecol Biogeogr 23:925-934. doi:10.1111/geb.12171

Brautigam K, Vining KJ, Lafon-Placette C, Fossdal CG, Mirouze M, Marcos JG, Fluch S, Fraga MF, Guevara MA, Abarca D, Johnsen O, Maury S, Strauss SH, Campbell MM, Rohde A, Diaz-Sala C, Cervera MT (2013) Epigenetic regulation of adaptive responses of forest tree species to the environment. Ecol Evol 3:399-415. doi:10. 1002/ece 3.461

Breed MF, Stead MG, Ottewell KM, Gardner MG, Lowe AJ (2013) Which provenance and where? Seed sourcing strategies for revegetation in a changing environment. Conserv Genet 14:1-10. doi:10. 1007/s10592-012-0425-Z

Breymeyer A, Melillo JM (1991) Global climate change - the effects of climate change on production and decomposition in coniferous forests and grasslands. Ecol Appl 1:111-111. doi:10.2307/1941804

Brooker RW, Travis JMJ, Clark EJ, Dytham C (2007) Modelling species' range shifts in a changing climate: the impacts of biotic interactions, dispersal distance and the rate of climate change. J Theor Biol 245: 59-65. doi:10.1016/j.jtbi.2006.09.033

Brotak EA, Reifsnyder WE (1977) Predicting major wildland fire occurrence. Fire Manag Notes 38:5-8

Brown HCP (2009) Climate change and Ontario forests: prospects for building institutional adaptive capacity. Mitig Adapt Strateg Glob Chang 14:513-536. doi:10.1007/s11027-009-9183-8

Buma B, Wessman CA (2013) Forest resilience, climate change, and opportunities for adaptation: a specific case of a general problem. For Ecol Manag 306:216-225. doi:10.1016/j.foreco.2013.06.044

Campbell EM, Saunders SC, Coates KD, Meidinger DV, MacKinnon A, O’Neil GA, MacKillop DJ, DeLong SC, Morgan. DG (2009) Ecological resilience and complexity: a theoretical framework for understanding and managing British Columbia's forest ecosystems in a changing climate. B.C. Min. For. Range, For. Sci. Prog., Victoria, B.C.

Cannell MGR, Grace J, Booth A (1989) Possible impacts of climatic warming on trees and forests in the United Kingdom - a review. Forestry 62:337-364. doi:10.1093/forestry/62.4.337

Carvalho A, Flannigan MD, Logan K, Miranda AI, Borrego C (2008) Fire activity in Portugal and its relationship to weather and the Canadian Fire Weather Index System. Int J Wildl Fire 17:328338. doi:10.1071/WF07014

Castagneri D, Motta R (2010) A research gap in the interactive effects of climate and competition on trees growth. In: Karam WP (ed) Tree growth: influences, layers and types. Nova Science, Hauppauge, pp 93-102

Caverley N (2013) The guardians of Mother Earth: a qualitative study of aboriginal knowledge keepers and their views on climate change adaptation in the South Selkirks region. Nativ Stud Rev 21:125-150

Cheaib A, Badeau V, Boe J, Chuine I, Delire C, Dufrêne E, François C, Gritti ES, Legay M, Pagé C, Thuiller W, Viovy N, Leadley P (2012) Climate change impacts on tree ranges: model intercomparison facilitates understanding and quantification of uncertainty. Ecol Lett 15:533-544. doi:10.1111/j.1461-0248.2012.01764.x

Chen WJ, Black TA, Yang PC, Barr AG, Neumann HH, Nesic Z, Blanken PD, Novak MD, Eley J, Ketler RJ, Cuenca A (1999) Effects of climatic variability on the annual carbon sequestration by a boreal aspen forest. Glob Chang Biol 5:41-53. doi:10.1046/j.1365-2486. 1998.00201.x

Chmura DJ, Anderson PD, Howe GT, Harrington CA, Halofsky JE, Peterson DL, Shaw DC, St. Brad Clair J (2011) Forest responses to climate change in the northwestern United States: ecophysiological foundations for adaptive management. For Ecol Manag 261: 1121-1142. doi:10.1016/j.foreco.2010.12.040

Choat B, Jansen S, Brodribb TJ, Cochard H, Delzon S, Bhaskar R, Bucci SJ, Feild TS, Gleason SM, Hacke UG, Jacobsen AL, Lens F, Maherali H, Martinez-Vilalta J, Mayr S, Mencuccini M, Mitchell PJ, Nardini A, Pittermann J, Pratt RB, Sperry JS, Westoby M, Wright IJ, Zanne AE (2012) Global convergence in the vulnerability of forests to drought. Nature 491:752-755

Chuvieco E, Martinez S, Roman MV, Hantson S, Pettinari ML (2014) Integration of ecological and socio-economic factors to assess global vulnerability to wildfire. Glob Ecol Biogeogr 23:245-258. doi:10. 1111/geb.12095

Clark DA (2007) Detecting tropical forests' responses to global climatic and atmospheric change: current challenges and a way forward. Biotropica 39:4-19. doi:10.1111/j.1744-7429.2006.00227.x

Clark JS, Bell DM, Hersh MH, Nichols L (2011) Climate change vulnerability of forest biodiversity: climate and competition tracking of demographic rates. Glob Chang Biol 17:1834-1849. doi:10.1111/j. 1365-2486.2010.02380.x

Cockfield G, Maraseni T, Buys L, Sommerfeld J, Wilson C, Athukorala W (2011) Socioeconomic implications of climate change with regard to forests and forest management. Contribution of Work Package 3 to the Forest Vulnerability Assessment. National Climate Change Adaptation Research Facility, Gold Coast

Corlett RT (2011) Impacts of warming on tropical lowland rainforests. Trends Ecol Evol 26:606-613

Corlett RT, Westcott DA (2013) Will plant movements keep up with climate change? Trends Ecol Evol 28:482-488. doi:10.1016/j.tree. 2013.04.003

Couture S, Reynaud A (2008) Multi-stand forest management under a climatic risk: do time and risk preferences matter? Environ Model Assess 13:181-193

D'Amato AW, Bradford JB, Fraver S, Palik BJ (2011) Forest management for mitigation and adaptation to climate change: insights from long-term silviculture experiments. For Ecol Manag 262:803-816. doi:10.1016/j.foreco.2011.05.014

Daubenmire RF (1978) Plant geography. Academic, New York

Davidar P, Rajagopal B, Mohandass D, Puyravaud JP, Condit R, Wright SJ, Leigh EG (2007) The effect of climatic gradients, topographic variation and species traits on the beta diversity of rain forest trees. Glob Ecol Biogeogr 16:510-518. doi:10.1111/j.1466-8238.2007. 00307.x

Davis MB (1986) Climatic instability, time lags and community disequilibrium. In: Diamond J, Case TJ (eds) Community ecology. Harper and Row, New York, pp 269-284

Day JK, Perez DM (2013) Reducing uncertainty and risk through forest management planning in British Columbia. For Ecol Manag 300: 117-124. doi:10.1016/j.foreco.2012.11.035

de Groot WJ, Flannigan MD, Cantin AS (2013) Climate change impacts on future boreal fire regimes. For Ecol Manag 294:35-44. doi:10. 1016/j.foreco.2012.09.027

Dessai S, Hulme M (2004) Does climate adaptation policy need probabilities? Clim Pol 4:107-128. doi:10.1080/14693062.2004.9685515

Di Nitto D, Neukermans G, Koedam N, Defever H, Pattyn F, Kairo JG, Dahdouh-Guebas F (2014) Mangroves facing climate change: landward migration potential in response to projected scenarios of sea level rise. Biogeosciences 11: 857-871. doi:10.5194/bg-11-857-2014 
Dixon RK, Krankina ON, Kobak KI (1996) Global climate change adaptation: examples from Russian boreal forests. Adapting to climate change: an international perspective.

Dobrowski SZ, Abatzoglou J, Swanson AK, Greenberg JA, Mynsberge AR, Holden ZA, Schwartz MK (2013) The climate velocity of the contiguous United States during the 20th century. Glob Chang Biol 19:241-251. doi:10.1111/gcb.12026

Doyle TW, Krauss KW, Conner WH, From AS (2010) Predicting the retreat and migration of tidal forests along the northern Gulf of Mexico under sea-level rise. For Ecol Manag 259:770-777. doi: 10.1016/j.foreco.2009.10.023

Eliasch J (2008) Climate change: financing global forests. The Eliasch Review. HMSO

Emanuel WR, Shugart HH, Stevenson MP (1985) Climatic-change and the broad-scale distribution of terrestrial ecosystem complexes. Clim Chang 7:29-43. doi:10.1007/bf00139439

Eriksson LO, Backéus S, Garcia F (2011) Implications of growth uncertainties associated with climate change for stand management. Eur J For Res 131:1199-1209. doi:10.1007/s10342-011-0591-4

Ettl GJ, Peterson DL (1995) Extreme climate and variation in tree growth-individualistic response in sub-alpine fir (Abieslasiocarpa). Glob Chang Biol 1:231-241. doi:10.1111/j.13652486.1995.tb00024.x

Feeley KJ, Rehm EM, Machovina B (2012) Perspective: the responses of tropical forest species to global climate change: acclimate, adapt, migrate, or go extinct? Frontiers of Biogeography 4 (2)

Feikema PM, Sherwin CB, Lane PNJ (2013) Influence of climate, fire severity and forest mortality on predictions of long term streamflow: potential effect of the 2009 wildfire on Melbourne's water supply catchments. J Hydrol 488:1-16. doi:10.1016/j.jhydrol.2013.02.001

Fischer AP, Paveglio T, Carroll M, Murphy D, Brenkert-Smith H (2013) Assessing social vulnerability to climate change in human communities near public forests and grasslands: a framework for resource managers and planners. J For 111:357-365. doi:10.5849/jof. 12-091

Fischlin A, Ayres M, Karnosky D, Kellomäki S, Louman B, Ong C, Plattner G-K, Santoso H, Thompson I, Booth TH, Marcar N, Scholes B, Swanston C, Zamolodchikov D (2009) Future environmental impacts and vulnerabilities. In: Seppälä R, Buck A, Katila P (eds) Adaptation of forests and people to climate change: a global assessment report, vol 22. IUFRO World Series, Helsinki, pp 53100

Franks PJ, Adams MA, Amthor JS, Barbour MM, Berry JA, Ellsworth DS, Farquhar GD, Ghannoum O, Lloyd J, McDowell N, Norby RJ, Tissue DT, von Caemmerer S (2013) Sensitivity of plants to changing atmospheric $\mathrm{CO} 2$ concentration: from the geological past to the next century. New Phytol 197:1077-1094. doi:10.1111/nph.12104

Furness E, Nelson H (2012) Community forest organizations and adaptation to climate change in British Columbia. For Chron 88:519-524

Garcia RA, Cabeza M, Rahbek C, Araújo MB (2014) Multiple dimensions of climate change and their implications for biodiversity. Science 344 (6183). doi:10.1126/science. 1247579

Gentilli J (1949) Forest influences: the effects of woody vegetation on climatic water, and soil, with applications to the conservation of water and the control of floods and erosion. Geogr Rev 39:164-164. doi: $10.2307 / 211169$

Gibbs HK, Ruesch AS, Achard F, Clayton MK, Holmgren P, Ramankutty N, Foley JA (2010) Tropical forests were the primary sources of new agricultural land in the 1980s and 1990s. Proc Natl Acad Sci 107: 16732-16737. doi:10.1073/pnas.0910275107

Gilman RT, Fabina NS, Abbott KC, Rafferty NE (2012) Evolution of plant-pollinator mutualisms in response to climate change. Evol Appl 5:2-16. doi:10.1111/j.1752-4571.2011.00202.x

Gonzalez ME, Lara A, Urrutia R, Bosnich J (2011) Climatic change and its potential impact on forest fire occurrence in south-central Chile (33 degrees-42 degrees S). Bosque 32:215-219. doi:10.4067/s071792002011000300002
Graham RL, Turner MG, Dale VH (1990) How increasing CO2 and climate change affect forests - at many spatial and temporal scales, there will be forest responses that will be affected by human activities. Bioscience 40:575-587. doi:10.2307/1311298

Graumlich LJ (1993) Response of tree growth to climatic variation in the mixed conifer and deciduous forests of the upper Great-Lakes region. Can J For Res 23:133-143. doi:10.1139/x93-020

Groffman PM, Rustad LE, Templer PH, Campbell JL, Christenson LM, Lany NK, Socci AM, Vadeboncoeur MA, Schaberg PG, Wilson GF, Driscoll CT, Fahey TJ, Fisk MC, Goodale CL, Green MB, Hamburg SP, Johnson CE, Mitchell MJ, Morse JL, Pardo LH, Rodenhouse NL (2012) Long-term integrated studies show complex and surprising effects of climate change in the northern hardwood forest. Bioscience 62:1056-1066. doi:10.1525/bio.2012.62.12.7

Grubb PJ, Whitmore TC (1966) A comparison of montane and lowland rain forest in Ecuador. 2. Climate and its effects on distribution and physiognomy of forests. J Ecol 54:303. doi:10.2307/2257951

Guan BT, Wright WE, Chung C-H, Chang S-T (2012) ENSO and PDO strongly influence Taiwan spruce height growth. For Ecol Manag 267:50-57. doi:10.1016/j.foreco.2011.11.028

Guardiola-Claramonte M, Troch PA, Breshears DD, Huxman TE, Switanek MB, Durcik M, Cobb NS (2011) Decreased streamflow in semi-arid basins following drought-induced tree die-off: a counter-intuitive and indirect climate impact on hydrology. J Hydrol 406:225-233. doi:10.1016/j.jhydrol.2011.06.017

Guariguata MR (2009) Tropical forest management and climate change adaptation. Rev Estud Soc 32:98-112

Guariguata MR, Cornelius JP, Locatelli B, Forner C, Sánchez-Azofeifa GA (2008) Mitigation needs adaptation: tropical forestry and climate change. Mitig Adapt Strateg Glob Chang 13:793-808. doi:10. 1007/s11027-007-9141-2

Guariguata MR, Locatelli B, Haupt F (2012) Adapting tropical production forests to global climate change: risk perceptions and actions. Int For Rev 14:27-38

Gyampoh BA, Amisah S, Idinoba M, Nkem J (2009) Using traditional knowledge to cope with climate change in rural Ghana. Unasylva 60:70-74

Hahn WA, Knoke T (2010) Sustainable development and sustainable forestry: analogies, differences, and the role of flexibility. Eur $\mathrm{J}$ For Res 129:787-801. doi:10.1007/s10342-010-0385-0

Hamrick JL (2004) Response of forest trees to global environmental changes. For Ecol Manag 197:323-335. doi:10.1016/j.foreco. 2004.05.023

Hansenbristow KJ, Ives JD, Wilson JP (1988) Climatic variability and tree response within the forest alpine tundra ecotone. Ann Assoc Am Geogr 78:505-519. doi:10.1111/j.1467-8306.1988.tb00221.x

Harper RJ, Smettem KRJ, Carter JO, McGrath JF (2009) Drought deaths in Eucalyptus globulus (Labill.) plantations in relation to soils, geomorphology and climate. Plant Soil 324:199-207. doi:10.1007/ s11104-009-9944-x

Heller NE, Zavaleta ES (2009) Biodiversity management in the face of climate change: a review of 22 years of recommendations. Biol Conserv 142:14-32. doi:10.1016/j.biocon.2008.10.006

Hennessy K, Lucas C, Nicholls N, Bathols J, Suppiah R, Ricketts J (2005) Climate change impacts on fire-weather in south-east Australia. CSIRO Division of Marine and Atmospheric Research, Aspendale

Holling CS (1978) Adaptive environmental assessment and management. Wiley, Chichester

Hughes L, Cawsey EM, Westoby M (1996) Climatic range sizes of Eucalyptus species in relation to future climate change. Glob Ecol Biogeogr Lett 5:23-29. doi:10.2307/2997467

Huntingford C, Zelazowski P, Galbraith D, Mercado LM, Sitch S, Fisher R, Lomas M, Walker AP, Jones CD, Booth BBB, Malhi Y, Hemming D, Kay G, Good P, Lewis SL, Phillips OL, Atkin OK, Lloyd J, Gloor E, Zaragoza-Castells J, Meir P, Betts R, Harris PP, 
Nobre C, Marengo J, Cox PM (2013) Simulated resilience of tropical rainforests to $\mathrm{CO} 2$-induced climate change. Nat Geosci 6: 268-273

Huntley B (1990) European postglacial forests - compositional changes in response to climatic-change. J Veg Sci 1:507-518. doi:10.2307/ 3235785

Ince PJ, Kramp AD, Skog KE, Yoo DI, Sample VA (2011) Modeling future U.S. forest sector market and trade impacts of expansion in wood energy consumption. J For Econ 17:142-156. doi:10.1016/j. jfe.2011.02.007

Innes J, Joyce LA, Kellomäki S, Louman B, Ogden A, Parrotta J, Thompson I, Ayres M, Ong C, Santoso H, Sohngen B, Wreford A (2009) Management for adaptation. In: Seppälä R, Buck A, Katila P (eds) Adaptation of forests and people to climate change: a global assessment report, vol World Series Volume 22. IUFRO Helsinki, pp $135-186$

IPCC (2013) Climate Change 2013: The physical science basis. Contribution of Working Group I to the Fifth Assessment Report of the Intergovernmental Panel on Climate Change [Stocker, T.F., D. Qin, G.-K. Plattner, M. Tignor, S.K. Allen, J. Boschung, A. Nauels, Y. Xia, V. Bex and P.M. Midgley (eds.)]. Cambridge, United Kingdom and New York, NY, USA

IUCN (2008) Ecosystem-based adaptation: an approach for building resilience and reducing risk for local communities and ecosystems. Submission to the Chair of the AWG-LCA with respect to the Shared Vision and Enhanced Action on Adaptation. International Union for the Conservation of Nature,

Iverson LR, Schwartz MW, Prasad AM (2004) How fast and far might tree species migrate in the eastern United States due to climate change? Glob Ecol Biogeogr 13:209-219

Johnson G, Sorensen FC, St Clair JB, Cronn RC (2004) Pacific Northwest forest tree seed zones: a template for native plants? Nativ Plants J 5:131-140

Johnston M, Hesseln H (2012) Climate change adaptive capacity of the Canadian forest sector. For Policy Econ 24:29-34. doi:10.1016/j. forpol.2012.06.001

Johnston M, Lindner M, Parrotta J, Giessen L (2012) Adaptation and mitigation options for forests and forest management in a changing climate. For Policy Econ 24:1-2. doi:10.1016/j.forpol.2012.09.007

Johnston M, Williamson T (2007) A framework for assessing climate change vulnerability of the Canadian forest sector. For Chron 83: 358-361

Joyce LA (2007) The impacts of climate change on forestry. In: Adams DM, Haynes RW (eds) Resource and market projections for forest policy development: twenty-five years of experience with the US RPA Timber Assessment, vol 14. Managing Forest Ecosystems. pp 449-488

Joyce LA, Blate GM, Littell JS, McNulty SG, Millar CI, Moser SC, Neilson RP, O'Halloran K, Peterson DL (2008) National forests. Preliminary review of adaptation options for climate-sensitive ecosystems and resources. A report by the U.S. Climate Change Science Program and the Subcommittee on Global Change Research. US Environmental Protection Agency, Washington, DC

Joyce LA, Blate GM, McNulty SG, Millar CI, Moser S, Neilson RP, Peterson DL (2009) Managing for multiple resources under climate change: national forests. Environ Manag 44:1022-1032. doi:10. 1007/s00267-009-9324-6

Joyce LA, Mills JR, Heath LS, McGuire AD, Haynes RW, Birdsey RA (1995) Forest sector impacts from changes in forest productivity under climate change. J Biogeogr 22:703-713. doi:10.2307/ 2845973

Kalame FB, Luukkanen O, Kanninen M (2011) Making the National Adaptation Programme of Action (NAPA) more responsive to the livelihood needs of tree planting farmers, drawing on previous experience in dryland Sudan. Forests 2:948-960. doi:10.3390/ f2040948
Kallarackal J, Roby TJ (2012) Responses of trees to elevated carbon dioxide and climate change. Biodivers Conserv 21:1327-1342. doi: 10.1007/s10531-012-0254-x

Kant P, Wu S (2012) Should adaptation to climate change be given priority over mitigation in tropical forests? Carbon Manag 3:303311. doi: $10.4155 / \mathrm{cmt} .12 .29$

Karjalainen T, Pussinen A, Liski J, Nabuurs GJ, Eggers T, Lapvetelainen T, Kaipainen T (2003) Scenario analysis of the impacts of forest management and climate change on the European forest sector carbon budget. For Policy Econ 5:141-155. doi:10.1016/s13899341(03)00021-2

Keenan RJ (2012) Adaptation of forests and forest management to climate change: an editorial. Forests 3:75-82. doi:10.3390/ f3010075

Kellomaki S, Peltola H, Nuutinen T, Korhonen KT, Strandman H (2008) Sensitivity of managed boreal forests in Finland to climate change, with implications for adaptive management. Phil Trans R Soc B 363:2341-2351. doi:10.1098/rstb.2007.2204

Kelly AE, Goulden ML (2008) Rapid shifts in plant distribution with recent climate change. Proc Natl Acad Sci 105:11823-11826. doi: 10.1073/pnas.0802891105

Kerhoulas LP, Kolb TE, Hurteau MD, Koch GW (2013) Managing climate change adaptation in forests: a case study from the US Southwest. J Appl Ecol 50:1311-1320. doi:10.1111/1365-2664. 12139

Keskitalo EC (2008) Vulnerability and adaptive capacity in forestry in northern Europe: a Swedish case study. Clim Chang 87:219-234. doi:10.1007/s10584-007-9337-1

Keskitalo ECH (2011) How can forest management adapt to climate change? Possibilities in different forestry systems. Forests 2:415430. doi:10.3390/f2010415

Kienast F, Brzeziecki B, Wildi O (1996) Long-term adaptation potential of Central European mountain forests to climate change: a GISassisted sensitivity assessment. For Ecol Manag 80:133-153. doi: 10.1016/0378-1127(95)03633-4

Kimmins JP (2002) Future shock in forestry - where have we come from; where are we going; is there a "right way" to manage forests? Lessons from Thoreau, Leopold, Toffler, Botkin and Nature. For Chron 78:263-271

Kimmins JP (2008) From science to stewardship: harnessing forest ecology in the service of society. For Ecol Manag 256:1625-1635. doi:10.1016/j.foreco.2008.02.057

Kimmins JP, Blanco JA, Seely B, Welham C, Scoullar K (2008) Complexity in modelling forest ecosystems: how much is enough? For Ecol Manag 256:1646-1658. doi:10.1016/j.foreco.2008.03.011

Kimmins JP, Mailly D, Seely B (1999) Modelling forest ecosystem net primary production: the hybrid simulation approach used in forecast. Ecol Model 122:195-224

Kint V, Aertsen W, Campioli M, Vansteenkiste D, Delcloo A, Muys B (2012) Radial growth change of temperate tree species in response to altered regional climate and air quality in the period 1901-2008. Clim Chang 115:343-363. doi:10.1007/s10584-012-0465-x

Kirschbaum MUF, Watt MS, Tait A, Ausseil A-GE (2012) Future wood productivity of Pinus radiata in New Zealand under expected climatic changes. Glob Chang Biol 18:1342-1356. doi:10.1111/j. 1365-2486.2011.02625.x

Klenk NL, Adams BW, Bull GQ, Innes JL, Cohen SJ, Larson BC (2011) Climate change adaptation and sustainable forest management: a proposed reflexive research agenda. For Chron 87:351-357

Kobak KI, Turchinovich IY, Kondrasheva NY, Schulze ED, Schulze W, Koch H, Vygodskaya NN (1996) Vulnerability and adaptation of the larch forest in eastern Siberia to climate change. Water Air Soil Pollut 92:119-127

Kolström M, Lindner M, Vilén T, Maroschek M, Seidl R, Lexer MJ, Netherer S, Kremer A, Delzon S, Barbati A, Marchetti M, Corona P (2011) Reviewing the science and Implementation of climate change 
adaptation measures in European forestry. Forests 2:961-982. doi: 10.3390/f2040961

Konkin D, Hopkins K (2009) Learning to deal with climate change and catastrophic forest disturbances. Unasylva 60:17-23

Kremer A, Ronce O, Robledo-Arnuncio JJ, Guillaume F, Bohrer G, Nathan R, Bridle JR, Gomulkiewicz R, Klein EK, Ritland K, Kuparinen A, Gerber S, Schueler S (2012) Long-distance gene flow and adaptation of forest trees to rapid climate change. Ecol Lett 15: 378-392. doi:10.1111/j.1461-0248.2012.01746.x

Kuparinen A, Savolainen O, Schurr FM (2010) Increased mortality can promote evolutionary adaptation of forest trees to climate change. For Ecol Manag 259:1003-1008. doi:10.1016/j.foreco.2009.12.006

Lal R, Cummings DJ (1979) Clearing a tropical forest. 1. Effects on soil and micro-climate. Field Crop Res 2:91-107. doi:10.1016/03784290(79)90012-1

Leites LP, Rehfeldt GE, Robinson AP, Crookston NL, Jaquish B (2012) Possibilities and limitations of using historic provenance tests to infer forest species growth responses to climate change. Nat Resour Model 25:409-433. doi:10.1111/j.1939-7445.2012.00129.x

Lenoir J, Gegout JC, Dupouey JL, Bert D, Svenning JC (2010) Forest plant community changes during 1989-2007 in response to climate warming in the Jura Mountains (France and Switzerland). J Veg Sci 21:949-964. doi:10.1111/j.1654-1103.2010.01201.x

Leuzinger S, Luo Y, Beier C, Dieleman W, Vicca S, Körner C (2011) Do global change experiments overestimate impacts on terrestrial ecosystems? Trends Ecol Evol 26:236-241

Levina E, Tirpak D (2006) Adaptation to climate change: key terms. OECD/IEA, Paris

Lin BB, Petersen B (2013) Resilience, regime shifts, and guided transition under climate change: examining the practical difficulties of managing continually changing systems. Ecology and Society 18 (1). doi:10.5751/es-05128-180128

Lindner M (2000) Developing adaptive forest management strategies to cope with climate change. Tree Physiol 20:299-307

Lindner M, Fitzgerald JB, Zimmermann NE, Reyer C, Delzon S, van der Maaten E, Schelhaas MJ, Lasch P, Eggers J, van der MaatenTheunissen M, Suckow F, Psomas A, Poulter B, Hanewinkel M (2014) Climate change and European forests: what do we know, what are the uncertainties, and what are the implications for forest management? J Environ Manag 146:69-83. doi:10.1016/j.jenvman. 2014.07.030

Lindner M, Maroschek M, Netherer S, Kremer A, Barbati A, GarciaGonzalo J, Seidl R, Delzon S, Corona P, Kolström M, Lexer MJ, Marchetti M (2010) Climate change impacts, adaptive capacity, and vulnerability of European forest ecosystems. For Ecol Manag 259: 698-709. doi:10.1016/j.foreco.2009.09.023

Lindner M, Sohngen B, Joyce LA, Price DT, Bernier PY, Karjalainen T (2002) Integrated forestry assessments for climate change impacts. For Ecol Manag 162:117-136. doi:10.1016/S0378-1127(02)00054-3

Littell JS, Peterson DL, Millar CI, O'Halloran KA (2012) U.S. national forests adapt to climate change through science-management partnerships. Clim Chang 110:269-296. doi:10.1007/s10584-011-00660

Liu Y, Stanturf J, Goodrick S (2010) Trends in global wildfire potential in a changing climate. For Ecol Manag 259:685-697. doi:10.1016/j. foreco.2009.09.002

Locatelli B, Evans V, Wardell A, Andrade A, Vignola R (2011) Forests and climate change in Latin America: linking adaptation and mitigation. Forests 2:431-450. doi:10.3390/f2010431

Loehman RA, Clark JA, Keane RE (2011) Modeling effects of climate change and fire management on Western White Pine (Pinus monticola) in the Northern Rocky Mountains, USA. Forests 2: 832-860. doi:10.3390/f2040832

Long A (2013) REDD plus, adaptation, and sustainable forest management: toward effective polycentric global forest governance. Trop Conserv Sci 6:384-408
Lucier A, Ayres M, Karnosky D, Thompson I, Loehle C, Percy K, Sohngen B (2009) Forest responses and vulnerabilities to recent climate change. In: Seppälä R, Buck A, Katila P (eds) Adaptation of forests and people to climate change: a global assessment report, vol World Series Volume 22. IUFRO Helsinki, pp 29-52

Lynch AJJ, Fell DG, McIntyre-Tamwoy S (2010) Incorporating Indigenous values with 'Western' conservation values in sustainable biodiversity management. Aust J Environ Manag 17:244-255

Macdonald GM, Edwards TWD, Moser KA, Pienitz R, Smol JP (1993) Rapid response of treeline vegetation and lakes to past climate warming. Nature 361:243-246. doi:10.1038/361243a0

Mahat V, Anderson A (2013) Impacts of climate and catastrophic forest changes on streamflow and water balance in a mountainous headwater stream in Southern Alberta. Hydrol Earth Syst Sci 17:49414956. doi:10.5194/hess-17-4941-2013

Malcolm JR, Markham A, Neilson RP, Garaci M (2002) Estimated migration rates under scenarios of global climate change. J Biogeogr 29:835-849. doi:10.1046/j.1365-2699.2002.00702.x

Matthews SN, Iverson LR, Prasad AM, Peters MP (2011) Changes in potential habitat of 147 North American breeding bird species in response to redistribution of trees and climate following predicted climate change. Ecography 34:933-945. doi:10.1111/j.1600-0587. 2011.06803.x

McEvoy D, Fünfgeld H, Bosomworth K (2013) Resilience and climate change adaptation: the importance of framing. Plan Pract Res 28: 280-293. doi:10.1080/02697459.2013.787710

Medlyn B, Zeppel M, Brouwers N, Howard K, O'Gara E, Hardy G, Lyons T, Li L, Evans B (2011) Biophysical impacts of climate change on Australia's forests. Contribution of Work Package 2 to the Forest Vulnerability Assessment. National Climate Change Adaptation Research Facility, Gold Coast

Messier C, Puettmann K, Coates DJ (2013) Managing forests as complex adaptive systems: building resilience to the challenge of global change. Earthscan, London

Michelot A, Breda N, Damesin C, Dufrene E (2012) Differing growth responses to climatic variations and soil water deficits of Fagus sylvatica, Quercus petraea and Pinus sylvestris in a temperate forest. For Ecol Manag 265:161-171. doi:10.1016/j.foreco.2011.10.024

Milad M, Schaich H, Konold W (2013) How is adaptation to climate change reflected in current practice of forest management and conservation? A case study from Germany. Biodivers Conserv 22: 1181-1202. doi: 10.1007/s10531-012-0337-8

Miles L, Grainger A, Phillips O (2004) The impact of global climate change on tropical forest biodiversity in Amazonia. Glob Ecol Biogeogr 13:553-565. doi:10.1111/j.1466-822X.2004.00105.x

Mok H-F, Arndt SK, Nitschke CR (2012) Modelling the potential impact of climate variability and change on species regeneration potential in the temperate forests of South-Eastern Australia. Glob Chang Biol 18:1053-1072. doi:10.1111/j.1365-2486.2011.02591.x

Mori AS, Spies TA, Sudmeier-Rieux K, Andrade A (2013) Reframing ecosystem management in the era of climate change: issues and knowledge from forests. Biol Conserv 165:115-127. doi:10.1016/j. biocon.2013.05.020

Namkoong G (2001) Forest genetics: pattern and complexity. Can J For Res 31:623-632. doi:10.1139/cjfr-31-4-623

Neukum C, Azzam R (2012) Impact of climate change on groundwater recharge in a small catchment in the Black Forest, Germany. Hydrogeol J 20:547-560. doi:10.1007/s10040-011-0827-x

Nilsson AE, Gerger Swartling Å, Eckerberg K (2012) Knowledge for local climate change adaptation in Sweden: challenges of multilevel governance. Local Environ 17:751-767. doi:10.1080/13549839. 2012.678316

Nitschke CR, Innes JL (2008a) Integrating climate change into forest management in South-Central British Columbia: an assessment of landscape vulnerability and development of a climate-smart 
framework. For Ecol Manag 256:313-327. doi:10.1016/j.foreco. 2008.04.026

Nitschke CR, Innes JL (2008b) A tree and climate assessment tool for modelling ecosystem response to climate change. Ecol Model 210: 263-277. doi:10.1016/j.ecolmodel.2007.07.026

Nkem J, Kalame FB, Idinoba M, Somorin OA, Ndoye O, Awono A (2010) Shaping forest safety nets with markets: adaptation to climate change under changing roles of tropical forests in Congo Basin. Environ Sci Pol 13:498-508. doi:10.1016/j.envsci.2010.06.004

Ogden AE, Innes J (2007a) Incorporating climate change adaptation considerations into forest management planning in the boreal forest. Int For Rev 9:713-733. doi:10.1505/ifor.9.3.713

Ogden AE, Innes JL (2007b) Perspectives of forest practitioners on climate change adaptation in the Yukon and Northwest Territories of Canada. For Chron 83:557-569

Ogden AE, Innes JL (2009) Application of structured decision making to an assessment of climate change vulnerabilities and adaptation options for sustainable forest management. Ecology and Society 14 (1). doi: 11

Ohlson DW, McKinnon GA, Hirsch KG (2005) A structured decisionmaking approach to climate change adaptation in the forest sector. For Chron 81:97-103

Otterman J, Chou MD, Arking A (1984) Effects of nontropical forest cover on climate. J Clim Appl Meteorol 23:762-767. doi:10.1175/ 1520-0450(1984)023<0762:eonfco >2.0.co;2

Parks CG, Bernier P (2010) Adaptation of forests and forest management to changing climate with emphasis on forest health: a review of science, policies and practices. For Ecol Manag 259:657-659. doi: 10.1016/s0378-1127(09)00903-7

Pastor J, Post WM (1988) Response of northern forests to CO2-induced climate change. Nature 334:55-58. doi:10.1038/334055a0

Pearson RG, Dawson TP (2003) Predicting the impacts of climate change on the distribution of species: are bioclimate envelope models useful? Glob Ecol Biogeogr 12:361-371. doi:10.1046/j.1466822X.2003.00042.X

Peel J, Godden L, Keenan RJ (2012) Climate change law in an era of multi-level governance. Transl Environ Law 1:245-280. doi:10. 1017/S2047102512000052

Peters EB, Wythers KR, Zhang SX, Bradford JB, Reich PB (2013) Potential climate change impacts on temperate forest ecosystem processes. Can J For Res 43:939-950. doi:10.1139/cjfr-2013-0013

Peterson DL, Millar CI, Joyce LA, Furniss MJ, Halofsky JE, Neilson RP, Morelli TL (2011) Responding to climate change in national forests: a guidebook for developing adaptation options. General Technical Report. USDA Forest Service, Pacific Northwest Research Station

Phillips OL, Lewis SL, Baker TR, Chao K-J, Higuchi N (2008) The changing Amazon forest. Phil Trans R Soc B 363:1819-1827. doi: 10.1098/rstb.2007.0033

Pinkard EA, Battaglia M, Bruce J, Leriche A, Kriticos DJ (2010) Processbased modelling of the severity and impact of foliar pest attack on eucalypt plantation productivity under current and future climates. For Ecol Manag 259:839-847. doi:10.1016/j.foreco.2009.06.027

Pojar J, Klinka K, Meidinger DV (1987) Biogeoclimatic ecosystem classification in British Columbia. For Ecol Manag 22:119-154

Pramova E, Locatelli B, Djoudi H, Somorin OA (2012) Forests and trees for social adaptation to climate variability and change. Wiley Interdiscip Rev Clim Chang 3:581-596. doi:10.1002/wcc.195

Prato T (2008) Conceptual framework for assessment and management of ecosystem impacts of climate change. Ecol Complex 5:329-338

Pretzsch H, Biber P, Schütze G, Uhl E, Rötzer T (2014) Forest stand growth dynamics in Central Europe have accelerated since 1870. Nat Commun 5. doi:10.1038/ncomms5967

Rastetter EB, Ryan MG, Shaver GR, Melillo JM, Nadelhoffer KJ, Hobbie JE, Aber JD (1991) A general biogeochemical model describing the responses of the $\mathrm{C}$ and $\mathrm{N}$ cycles in terrestrial ecosystems to changes in CO2, climate, and N deposition. Tree Physiol 9:101-126
Rayner J, McNutt K, Wellstead A (2013) Dispersed capacity and weak coordination: the challenge of climate change adaptation in Canada's forest policy sector. Rev Policy Res 30:66-90. doi:10. 1111/ropr.12003

Regniere J (2009) Predicting insect continental distributions from species physiology. Unasylva 60:37-42

Reyer C, Lasch-Born P, Suckow F, Gutsch M, Murawski A, Pilz T (2014) Projections of regional changes in forest net primary productivity for different tree species in Europe driven by climate change and carbon dioxide. Ann For Sci 71:211-225. doi:10.1007/s13595-013-0306-8

Rigling A, Bigler C, Eilmann B, Feldmeyer-Christe E, Gimmi U, Ginzler C, Graf U, Mayer P, Vacchiano G, Weber P, Wohlgemuth T, Zweifel R, Dobbertin M (2013) Driving factors of a vegetation shift from Scots pine to pubescent oak in dry Alpine forests. Glob Chang Biol 19:229-240. doi: $10.1111 / \mathrm{gcb} .12038$

Rist L, Moen J (2013) Sustainability in forest management and a new role for resilience thinking. For Ecol Manag 310:416-427. doi:10.1016/ j.foreco.2013.08.033

Roberts G, Parrotta J, Wreford A (2009) Current adaptation measures and policies. In: Seppälä R, Buck A, Katila P (eds) Adaptation of forests and people to climate change: a global assessment report, vol World Series Volume 22. IUFRO Helsinki, pp 123-134

Ruiz-Labourdette D, Schmitz MF, Pineda FD (2013) Changes in tree species composition in Mediterranean mountains under climate change: indicators for conservation planning. Ecol Indic 24:310 323. doi:10.1016/j.ecolind.2012.06.021

Running SW, Nemani RR (1991) Regional hydrologic and carbon balance responses of forests resulting from potential climate change. Clim Chang 19:349-368. doi:10.1007/bf00151173

Sample VA, Halofsky JE, Peterson DL (2014) US strategy for forest management adaptation to climate change: building a framework for decision making. Ann For Sci 71:125-130. doi:10.1007/s13595013-0288-6

Schaich H, Milad M (2013) Forest biodiversity in a changing climate: which logic for conservation strategies? Biodivers Conserv 22: 1107-1114. doi:10.1007/s10531-013-0491-7

Schoene DHF, Bernier PY (2012) Adapting forestry and forests to climate change: a challenge to change the paradigm. For Policy Econ 24:1219. doi:10.1016/j.forpol.2011.04.007

Schwartz MW, Dolanc CR, Gao H, Strauss SY, Schwartz AC, Williams JN, Tang Y (2013) Forest structure, stand composition, and climategrowth response in montane forests of Jiuzhaigou National Nature Reserve, China. Plos One 8 (8). doi:10.1371/journal.pone.0071559

Scott D (2005) Integrating climate change into Canada's National Parks System. In: Lovejoy T, Hannah L (eds) Climate change and biodiversity. Yale University Press, New Haven, pp 343-345

Seidl R, Lexer MJ (2013) Forest management under climatic and social uncertainty: trade-offs between reducing climate change impacts and fostering adaptive capacity. J Environ Manag 114:461-469. doi:10.1016/j.jenvman.2012.09.028

Seidl R, Rammer W, Lexer MJ (2011) Adaptation options to reduce climate change vulnerability of sustainable forest management in the Austrian Alps. Can J For Res 41:694-706. doi:10.1139/x10-235

Seppala R (2009) A global assessment on adaptation of forests to climate change. Scand J For Res 24:469-472. doi:10.1080/ 02827580903378626

Seppälä R, Buck A, Katila P (2009) Adaptation of forests and people to climate change: a global assessment report, vol World Series Volume 22. Helsinki, IUFRO

Six DL (2009) Climate change and mutualism. Nat Rev Microbiol 7:686686

Somorin OA, Brown HCP, Visseren-Hamakers IJ, Sonwa DJ, Arts B, Nkem J (2012) The Congo Basin forests in a changing climate: Policy discourses on adaptation and mitigation (REDD+). Glob Environ Chang 22:288-298. doi:10.1016/j.gloenvcha.2011.08.001 
Sonwa DJ, Somorin OA, Jum C, Bele MY, Nkem JN (2012) Vulnerability, forest-related sectors and climate change adaptation: the case of Cameroon. For Policy Econ 23:1-9. doi:10.1016/j. forpol.2012.06.009

Sork VL, Aitken SN, Dyer RJ, Eckert AJ, Legendre P, Neale DB (2013) Putting the landscape into the genomics of trees: approaches for understanding local adaptation and population responses to changing climate. Tree Genet Genome 9:901-911. doi:10.1007/s11295013-0596-x

Spathelf $\mathrm{P}$, van der Maaten E, van der Maaten-Theunissen M, Campioli M, Dobrowolska D (2014) Climate change impacts in European forests: the expert views of local observers. Ann For Sci 71:131137. doi:10.1007/s13595-013-0280-1

Spies TA, Giesen TW, Swanson FJ, Franklin JF, Lach D, Johnson KN (2010) Climate change adaptation strategies for federal forests of the Pacific Northwest, USA: ecological, policy, and socio-economic perspectives. Landsc Ecol 25:1185-1199. doi:10.1007/s10980010-9483-0

Spittlehouse DL (2005) Integrating climate change adaptation into forest management. For Chron 81:691-695

Spittlehouse DL, Stewart RB (2003) Adaption to climate change in forest management. BCJ Ecosyst Manag 4:1-11

Stafford Smith M, Horrocks L, Harvey A, Hamilton C (2011) Rethinking adaptation for a 4 degrees $\mathrm{C}$ world. Philos Transact A Math Phys Eng Sci 369:196-216

Stainforth DA, Allen MR, Tredger ER, Smith LA (2007) Confidence, uncertainty and decision-support relevance in climate predictions. Philos Trans R Soc A Math Phys Eng Sci 365:2145-2161. doi:10. 1098/rsta.2007.2074

Stanturf JA, Palik BJ, Dumroese RK (2014) Contemporary forest restoration: a review emphasizing function. For Ecol Manag 331:292323

Steenberg JWN, Duinker PN, Bush PG (2011) Exploring adaptation to climate change in the forests of central Nova Scotia, Canada. For Ecol Manag 262:2316-2327. doi:10.1016/j.foreco.2011.08.027

Stephens M, Pinkard L, Keenan RJ (2012) Plantation forest industry climate change adaptation handbook. Australian Forest Products Association, Canberra

Tacconi L, Moore PF, Kaimowitz D (2007) Fires in tropical forestswhat is really the problem? Lessons from Indonesia. Mitig Adapt Strateg Glob Chang 12:55-66. doi:10.1007/s11027-006-9040-y

Temperli C, Bugmann H, Elkin C (2012) Adaptive management for competing forest goods and services under climate change. Ecol Appl 22:2065-2077

Thackway R, Cresswell ID (1992) Environmental regionalisations of Australia: a user-oriented approach. Environmental Resources Information Network, Canberra

Thomalla F, Downing T, Spanger-Siegfried E, Han GY, Rockstrom J (2006) Reducing hazard vulnerability: towards a common approach between disaster risk reduction and climate adaptation. Disasters 30: 39-48. doi:10.1111/j.1467-9523.2006.00305.x

Thomson-Reuters (2014) Web of Science. http://thomsonreuters.com/ thomson-reuters-web-of-science/. Accessed 21 Aug 2014

Thuiller W, Albert C, Araújo MB, Berry PM, Cabeza M, Guisan A, Hickler T, Midgley GF, Paterson J, Schurr FM, Sykes MT, Zimmermann NE (2008) Predicting global change impacts on plant species' distributions: future challenges. Perspect Plant Ecol Evol Syst 9:137-152. doi:10.1016/j.ppees.2007.09.004

Toffler A (1970) Future shock. Bantam, Toronto

Tompkins EL, Adger WN, Boyd E, Nicholson-Cole S, Weatherhead K, Arnell N (2010) Observed adaptation to climate change: UK evidence of transition to a well-adapting society. Glob Environ Chang Hum Policy Dimens 20:627-635. doi:10.1016/j.gloenvcha.2010. 05.001

Urwin K, Jordan A (2008) Does public policy support or undermine climate change adaptation? Exploring policy interplay across different scales of governance. Glob Environ Chang Hum Policy Dimens 18:180-191. doi:10.1016/j.gloenvcha.2007.08.002

Van Damme L (2008) Can the forest sector adapt to climate change? For Chron 84:633-634

van Dijk AIJM, Keenan RJ (2007) Planted forests and water in perspective. For Ecol Manag 251:1-9. doi:10.1016/j.foreco.2007.06.010

Versini PA, Velasco M, Cabello A, Sempere-Torres D (2013) Hydrological impact of forest fires and climate change in a Mediterranean basin. Nat Hazards 66:609-628. doi:10.1007/ s11069-012-0503-z

Vignola R, Locatelli B, Martinez C, Imbach P (2009) Ecosystem-based adaptation to climate change: what role for policy-makers, society and scientists? Mitig Adapt Strateg Glob Chang 14:691-696. doi: 10.1007/s11027-009-9193-6

Vihervaara P, D'Amato D, Forsius M, Angelstam P, Baessler C, Balvanera P, Boldgiv B, Bourgeron P, Dick J, Kanka R, Klotz S, Maass M, Melecis V, Petrik P, Shibata H, Tang JW, Thompson J, Zacharias S (2013) Using long-term ecosystem service and biodiversity data to study the impacts and adaptation options in response to climate change: insights from the global ILTER sites network. Curr Opin Environ Sustain 5:53-66. doi:10.1016/j.cosust.2012.11. 002

von Detten R, Faber F (2013) Organizational decision-making by German state-owned forest companies concerning climate change adaptation measures. For Policy Econ 35:57-65. doi:10.1016/j. forpol.2013.06.009

Walker B, Meyers JA (2004) Thresholds in ecological and socialecological systems: a developing database. Ecology and Society 9 (2)

Walker B, Salt D (2012) Resilience practice: engaging the sources of our sustainability. Island Press, Washington, DC

Wang T, Campbell EM, O’Neill GA, Aitken SN (2012) Projecting future distributions of ecosystem climate niches: uncertainties and management applications. For Ecol Manag 279:128-140. doi:10.1016/j. foreco.2012.05.034

Wellstead A, Rayner J, Howlett M (2014) Beyond the black box: forest sector vulnerability assessments and adaptation to climate change in North America. Environ Sci Pol 35:109-116. doi:10.1016/j.envsci. 2013.04.002

Westerling AL, Gershunov A, Cayan DR, Barnett TP (2002) Long lead statistical forecasts of area burned in western US wildfires by ecosystem province. Int J Wildl Fire 11:257-266. doi:10.1071/ wf02009

Westerling AL, Hidalgo HG, Cayan DR, Swetnam TW (2006) Warming and earlier spring increase western U.S. forest wildfire activity. Science 313:940-943. doi:10.1126/science.1128834

White A, Hatcher J, Khare A, Liddle M, Molnar A, Sunderlin WD (2010) Seeing people through the trees and the carbon: mitigating and adapting to climate change without undermining rights and livelihoods. Social dimensions of climate change: equity and vulnerability in a warming world: $277-301$

Wilby RL, Dessai S (2010) Robust adaptation to climate change. Weather 65:180-185. doi:10.1002/wea.543

Williams J (2013) Exploring the onset of high-impact mega-fires through a forest land management prism. For Ecol Manag 294:4-10. doi:10. 1016/j.foreco.2012.06.030

Williams JE (2000) The biodiversity crisis and adaptation to climate change: a case study from Australia's forests. Environ Monit Assess 61:65-74. doi:10.1023/a:1006361917359

Williams JT (2004) Managing fire-dependent ecosystems: we need a public lands policy debate. Fire Manag Today 64:6-11

Wintle BA, Bekessy SA, Keith DA, van Wilgen BW, Cabeza M, Schroder B, Carvalho SB, Falcucci A, Maiorano L, Regan TJ, Rondinini C, Boitani L, Possingham HP (2011) Ecologicaleconomic optimization of biodiversity conservation under climate change. Nat Clim Chang 1:355-359. doi:10.1038/nclimate1227 
Wu HX, Ying CC (2004) Geographic pattern of local optimality in natural populations of lodgepole pine. For Ecol Manag 194:177-198. doi: 10.1016/j.foreco.2004.02.017

Yousefpour R, Jacobsen JB, Meilby H, Thorsen BJ (2014) Knowledge update in adaptive management of forest resources under climate change: a Bayesian simulation approach. Ann For Sci 71:301-312. doi:10.1007/s13595-013-0320-x

Yousefpour R, Jacobsen JB, Thorsen BJ, Meilby H, Hanewinkel M, Oehler K (2011) A review of decision-making approaches to handle uncertainty and risk in adaptive forest management under climate change. Ann For Sci 69:1-15. doi:10.1007/s13595-0110153-4
Zhao D, Wu S, Yin Y (2013) Responses of terrestrial ecosystems' net primary productivity to future regional climate change in China. PLoS ONE 8:e60849. doi:10.1371/journal.pone.0060849

Zhou GY, Wei XH, Wu YP, Liu SG, Huang YH, Yan JH, Zhang DQ, Zhang QM, Liu JX, Meng Z, Wang CL, Chu GW, Liu SZ, Tang XL, Liu XD (2011) Quantifying the hydrological responses to climate change in an intact forested small watershed in Southern China. Glob Chang Biol 17: 3736-3746. doi:10.1111/j.1365-2486.2011.02499.x

Zimmermann NE, Yoccoz NG, Edwards TC, Meier ES, Thuiller W, Guisan A, Schmatz DR, Pearman PB (2009) Climatic extremes improve predictions of spatial patterns of tree species. Proc Natl Acad Sci 106:19723-19728. doi:10.1073/pnas.0901643106 